\title{
Osteotropic cytokines mediate human osteoblast-like cell eicosanoid production
}

Anurag Grover

West Virginia University

Follow this and additional works at: https://researchrepository.wvu.edu/etd

\section{Recommended Citation}

Grover, Anurag, "Osteotropic cytokines mediate human osteoblast-like cell eicosanoid production" (2005). Graduate Theses, Dissertations, and Problem Reports. 4151.

https://researchrepository.wvu.edu/etd/4151

This Thesis is protected by copyright and/or related rights. It has been brought to you by the The Research Repository @ WVU with permission from the rights-holder(s). You are free to use this Thesis in any way that is permitted by the copyright and related rights legislation that applies to your use. For other uses you must obtain permission from the rights-holder(s) directly, unless additional rights are indicated by a Creative Commons license in the record and/ or on the work itself. This Thesis has been accepted for inclusion in WVU Graduate Theses, Dissertations, and Problem Reports collection by an authorized administrator of The Research Repository @ WVU. For more information, please contact researchrepository@mail.wvu.edu. 
Osteotropic Cytokines mediate human osteoblast-like cell eicosanoid

$$
\text { production }
$$

\author{
Anurag Grover \\ Thesis submitted to the College of Arts and Sciences \\ at West Virginia University \\ in partial fulfillment of the requirements \\ for the degree of \\ Master of Science \\ in Biology
}

Philip Keeting, Ph.D., Chair Christy Foran, Ph.D.

Jorge Flores, Ph.D.

Department of Biology

Morgantown, West Virginia

2005

Keywords: Osteoporosis, Cytokines, $\mathrm{PGE}_{2}$ Synthases, Eicosanoids Copyright 2005 Anurag Grover 


\section{ABSTRACT \\ Osteotropic Cytokines mediate human osteoblast-like cell eicosanoid production.}

\section{Anurag Grover}

Because of its high incidence and devastating socio-economic consequences, osteoporosis is an important disorder of the aging population. To treat and to prevent this disorder the basic physiological mechanisms regulating bone cell biology must be understood. Bone remodeling is regulated by systemic hormones such as parathyroid hormone, glucocorticoids, estrogen, 1,25-dihydroxyvitamin $\mathrm{D}_{3}$ $\left(1,25(\mathrm{OH})_{2} \mathrm{D}_{3}\right)$, and by local factors such as cytokines, growth factors, and prostaglandins, which affects cells of the osteoclast or osteoblast lineage.

The regulation of bone metabolism by hormones has been extensively studied, but it is now clear that locally produced, nonsystemic, autocrine and paracrine factors play a direct and important role in bone remodeling. Eicosanoids (e.g. prostaglandins, HETEs, leukotrienes) are key components of a target cell's early responses to various stimulators including growth factors, cytokines, and hormones.

We have examined the effects of the cytokines tumor necrosis factor $\alpha$ (TNF), transforming growth factor $\beta$ (TGF $\beta$ ) and the effect of cyclooxygenase inhibitor ibuprofen on prostaglandin and 15-HETE biosynthesis by normal adult human osteoblast-like (hOB) cells. In the present studies, conditioned media harvested from hOB cell cultures were assayed by eicosanoid specific EIAs to determine quantitatively the effects of cytokines on $\mathrm{PGE}_{2}, 6$-keto-PGF $1 \alpha, \mathrm{PGF}_{2 \alpha}, \mathrm{PGD}_{2}$, thromboxane $\left(\mathrm{TXB}_{2}\right)$ and on 15-HETE biosynthesis. EIA analysis indicated that $\mathrm{PGE}_{2}$ was the predominant PG metabolite released by unstimulated hOB cells and its synthesis was increased more than other PGs in cells treated with TGF $\beta$ and TNF $\alpha$, both separately and in combination. $\mathrm{TXB}_{2}$ was not detected in control samples, or in samples stimulated with cytokines. 15-HETE was produced by the hOB cells, and was sensitive to modulation by the cytokines and ibuprofen.

The possibility that the up-regulation of $\mathrm{PGE}_{2}$ synthesis elicited by cytokines might have resulted from an increased level of the terminal $\mathrm{PGE}_{2}$ synthases (cPGES and mPGES) was tested. Transcripts for cPGES and mPGES was assessed by the reverse-transcriptase polymerase chain reaction using specific primers for human cPGES and mPGES. Upon dual cytokine stimulation, a significant up-regulation of cPGES and mPGES mRNA was observed.

The steady-state level of 15-Lipoxygenase type-II mRNA in the hOB cells was determined in control samples and specimens treated with TGF $\beta$ and/or TNF $\alpha$, IL-3 and IL-1 $\beta$. A significant increase in 15-LOX type-II mRNA level was evident in specimens treated with TNF $\alpha$ alone $(47.9 \pm 22$ fold-basal).

Thus, these studies indicate that TGF $\beta$ and/or TNF $\alpha$ modulate AA metabolism and upregulation of $\mathrm{PGE}_{2}$ synthesis elicited by these cytokines might have resulted from an increased level of the terminal PGE 2 synthases in hOB cells. 


\section{ACKNOWLEDGMENTS}

It is my privilege to express my sincere thanks and deep sense of gratitude to Dr. Philip Keeting, whose able supervision and constructive guidance led to the completion of this study. His constant involvement and unfailing encouragement remained with me throughout the course of this study. Aside from his help with the project, he has always been very understanding, sensitive and helpful about everything. I am very grateful to have Dr. Keeting as my mentor and advisor. I also express my gratitude to my committee members, Dr. Jorge Flores, and Dr. Christy Foran for critical review of my thesis.

My special thanks are due to Dr. Ashok Bidwai not only for his help but also for being very personal to me.

I also thank Dr. Frank Secreto for training me in cell culture work that had been very important in completing my degree.

I would also like to thank Maricica Pacurari for being a good friend. I will always remember our lively and funny conversations in the office and during lab work.

I find it difficult to verbalize my deepest sense of indebtedness to my parents for their boundless love and support, which has always been a source of inspiration, which really kept me going to come to this stage. 


\section{TABLE of CONTENTS}

Page

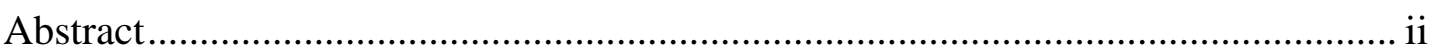

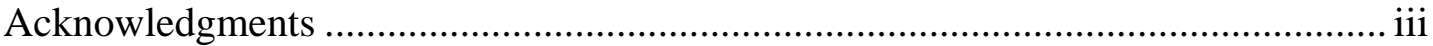

Table of Contents..................................................................................................... iv

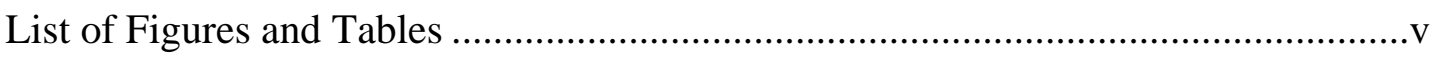

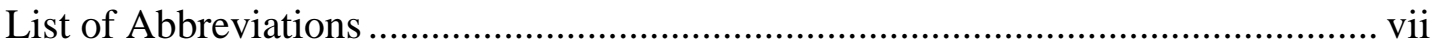

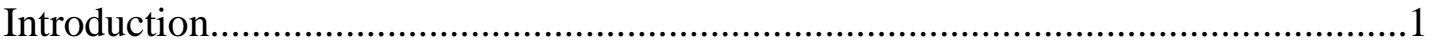

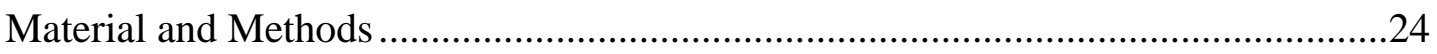

Patient Population..................................................................................24

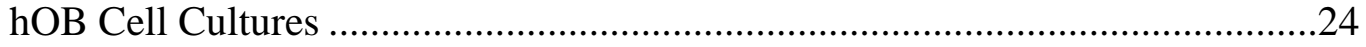

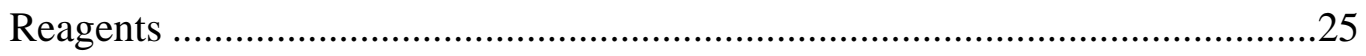

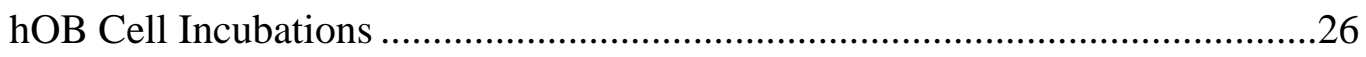

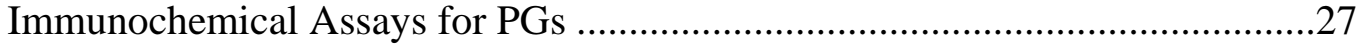

Reverse Transcription-Polymerase Chain Reaction (RT-PCR) ........................28

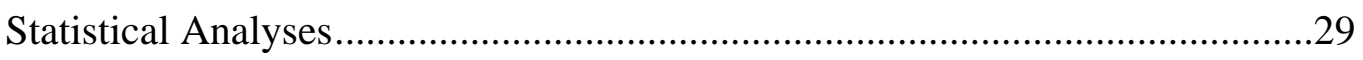

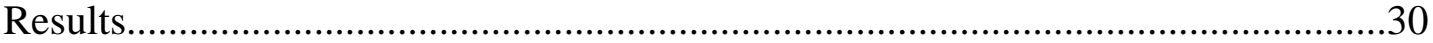

Effects of cytokines on biosynthesis of arachidonic acid metabolites ................30

Effect of cytokines on Prostaglandin $\mathrm{E}_{2}$ synthases ..........................................41

Effect of cytokines on 15-lipoxygenase type-II .............................................44

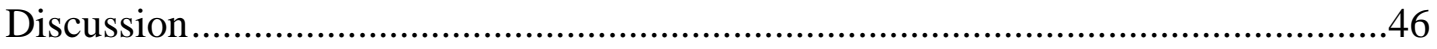

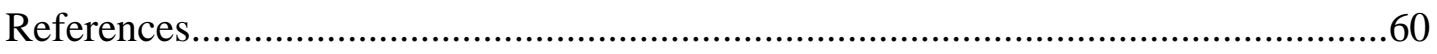




\section{LIST OF FIGURES AND TABLES}

\section{Title}

Page

Figure 1 Functional syncytium comprising osteocytes, osteoblasts, bone marrow stromal cells, and endothelial cells .................................... 7

Table 1 Vital statistics of adult bone remodeling............................. 9

Figure 2 Bone remodeling............................................ 10

Figure 3 The three major pathways involved in arachidonic acid metabolism..... 20

Figure 4 Thin layer chromatographic separation of 1-[14 C]AA radiolableled lipids from hOB cells..................................................... 30

Figure 5 Summary of PGs and 15-HETE stimulation by TGF- $\beta$ and TNF- $\alpha \ldots \ldots . .32$

Table 2 Effect of cytokines and Ibuprofen on PGE 2 synthesis by hOB cells....... 34

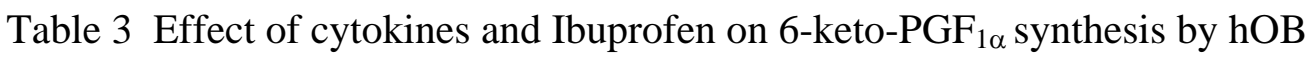
cells................................................................ 35

Table 4 Effect of cytokines and Ibuprofen on $\mathrm{PGF}_{2 \alpha}$ synthesis by hOB cells..... 36

Table 5 Effect of cytokines and Ibuprofen on $\mathrm{PGD}_{2}$ synthesis by hOB cells....... 38

Table 6 Effect of cytokines and Ibuprofen on 15-HETE synthesis by hOB cells... 39

Figure 6 RT-PCR based experiments to test whether the mRNA level of cPGES was sensitive to TGF $\beta$ and/or TNF $\alpha$ treatment............................... 42 
Figure 7 RT-PCR based experiments to test whether the mRNA level of mPGES was sensitive to TGF $\beta$ and/or TNF $\alpha$ treatment.................................. 43

Figure 8a RT-PCR based experiments to test whether the mRNA level of 15lipoxygenase type-II was sensitive to TGF $\beta$ and/or TNF $\alpha$, IL-3 and IL-1 $\beta$

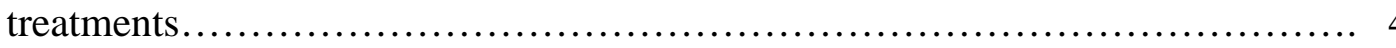

Figure 8b RT-PCR based experiments to test whether the mRNA level of 15lipoxygenase type- 2 was sensitive to TGF $\beta$ and/or TNF $\alpha$, IL-3 and IL-1 $\beta$

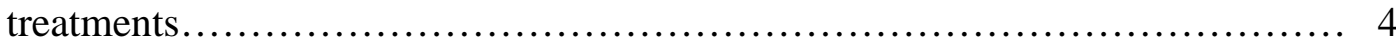


AA

BSA

COX

cPGES

DMEM

EIA

FCS

HETE

hOB

IL-1

LOX

MPGES

NSAID

OB

OC

PG

$\mathrm{PGE}_{2}$

$\mathbf{P G F}_{2 \alpha}$

PG $\mathbf{I}_{2}$

PG $\mathrm{H}_{2}$

$\mathrm{PLA}_{2}$

PTH

RIA

RT-PCR

TGF- $\beta$

TLC

TNF- $\alpha$

$\mathbf{T x B}_{2}$

6-k-PGF $1 \alpha$

\section{ABBREVIATIONS}

arachidonic acid

bovine serum albumin

cyclooxygenase

cytosolic prostaglandin $\mathrm{E}_{2}$ synthase

Dulbecco's Modified Eagle Medium

enzymeimmunoassay

fetal calf serum

hydroxyeicosatetraenoic acids

human osteoblast-like

interleukin-1

lipooxygenase

microsomal prostaglandin $\mathrm{E}_{2}$ synthase

non-steroidal anti-inflammatory drugs

osteoblasts

osteoclasts

prostaglandins

prostaglandin $\mathrm{E}_{2}$

prostaglandin $\mathbf{F}_{2 \alpha}$

prostaglandin $\mathrm{G} / \mathrm{H}$ synthase

prostaglandin $\mathbf{I}_{2}$

phospholipase $\mathbf{A}_{2}$

parathyroid hormone

radioimmunoassay

reverse transcriptase-polymerase chain reaction transforming growth factor-beta

thin layer chromatography

tumor necrosis factor-alpha

thromboxane

6-keto- prostaglandin $F_{\alpha}$ 


\section{INTRODUCTION}

Osteoporosis is a skeletal disorder in which bone strength is compromised due to the loss of bone density and bone quality (Inzerillo et al., 2002). It is characterized by low bone mass as well as by the micro architectural deterioration of bone with a consequent increase in bone fragility and sensitivity to fractures following minimal trauma (Riggs et al., 1992). Efforts have been primarily concentrated on the development of drugs that block bone resorption by decreasing the formation of osteoclasts or the activity of the osteoclasts. Inhibition of bone resorption can be accomplished by reducing either osteoclast generation (with estrogen or selective estrogen receptor modulators) or osteoclast activity (with calcitonin or bisphosphonates) (Stepan et al., 2003). Parathyroid hormone has become available as the first anabolic agent that increases bone formation (Hodsman et al., 1997). To date, these drugs and hormones have been the backbone of osteoporosis treatment and the prevention of fractures (Allen, 1993, Prestwood et al., 1998).

Notwithstanding the available effective therapies, osteoporosis is the most commonly occuring bone disease, and it is expected that the prevalence of osteoporosis will increase as the population ages (Fontanges et al., 2004). It affects approximately 28 million people in the United States, mostly post menopausal women, due to an accelerated rate of bone loss at and following the menopause (Hightower, 2000). Among significant chronic ailments in the U.S., 28 million people are affected with osteoporosis compared with 52 million and 42 million afflicted by hypercholesterolemia and by hypertension, respectively (Natarajan et al., 
2003). Health care costs of fractures resulting from osteoporosis were estimated to be $\$ 10$ to $\$ 18$ billion per year in the U.S.A in 1997 , and these costs are predicted to grow to more than $\$ 60$ billion per year by the year 2020 (Ray et al., 1997).

Bone is a dynamic living tissue that protects the body's internal organs, provides sites for muscle attachment for locomotion, and serves such physiological functions as maintaining calcium and phosphate balances in the body, and providing a site for the production of haemopoietic tissues (Rho et al., 2004). In adults, bone undergoes a continous process of remodeling, that is, the replacing of old and damaged bone with newly formed bone (Eriksen et al., 1994; Jilka et al., 1994). Osteoporosis results from defective bone remodeling regulation: the main problem is an imbalance between the rates of bone resorption and bone formation such that resorption exceeds formation particularly in cancellous bone (Raisz et al., 1984). In adults, approximately $25 \%$ of cancellous bone is resorbed and replaced every year, as compared with only 3\% of cortical bone (Seeman, 2003). Cancellous bone has a high surface-to-volume ratio with 70 to $85 \%$ of the surface of the trabecular bone in contact with the bone marrow (Islam et al., 1990). In addition to their anatomical concurrence, cells of the bone and the haemopoietic bone marrow share progenitors, produce and respond to some of the same cytokines and colony-stimulating factors, and are ultimately essential for each other’s function (Prockop, 1997).

Bone is composed of four different cell types (Fig. 1.). Osteoblasts, osteoclasts, and bone lining cells are present on bone surfaces, whereas osteocytes permeate the mineralized interior. Osteoblasts, lining cells, and osteocytes are all cells of the osteoblast lineage and osteoclasts are derived from precursors originating 
in the bone marrow (Manolagas et al., 1995; Manolagas et al., 1995). The precursors of osteoblasts are multipotent mesenchymal stem cells, which also give rise to bone marrow stromal cells, chondrocytes, muscle cells, and adipocytes (Owen, 1985;

Ghilzon et al., 1999; Hirschi et al., 2002) whereas the precursors of osteoclasts are hematopoietic cells of the monocyte/macrophage lineage (Vaes, 1988; Suda et al., 1992; Roodman, 1996). Long before osteoblasts could be cultured, the existence of multipotent mesenchymal stem cells was suspected, based on the evidence that fibroblastic colonies formed in cultures of adherent bone marrow cells can differentiate, under suitable stimuli, into each of the above mentioned cells; these progenitors were named colony forming unit fibroblasts (CFU-F) (Castro-Malaspina et al., 1984; Pittenger et al., 1999). When CFU-F are cultured in the presence of $\beta$ glycerophosphate and ascorbic acid, the majority of the colonies form a mineralized bone nodule; these bone-forming colonies are known as CFU-osteoblast (CFU-OB) (McCulloch et al., 1991; Malaval et al., 1994). Osteoblast precursors may originate not only from stromal mesenchymal progenitors of the marrow, but also from pericytes, mesenchymal cells that are adherent to the endothelial layer of blood vessels penetrating bone tissue (Schor et al., 1995). Whereas osteoclast precursors reach bone from the circulation, osteoblast precursors most probably reach bone by the migration of progenitors from neighboring connective tissues (Manolagas, 2000).

Fully differentiated osteoblasts produce and secrete proteins that make up the organic phase of bone matrix (Rifas et al., 1989). The proteinaceous matrix is subsequently mineralized under the control of the same cells (Masi et al., 2001; Mulari et al., 2004). A major protein product of the bone-forming osteoblast is type 
I collagen and it is a useful bone-formation marker (Abildgaard et al., 2004). This polymeric protein is initially secreted in the form of a precursor, which contains peptide extensions at both the amino-terminal and the carboxyl end of the molecule. The propeptide extensions are proteolytically removed. Further extracellular processing results in mature three-chained type I collagen molecules, which then assemble themselves into a collagen fibril (Imamura et al., 1998). Individual collagen molecules become interconnected by the formation of pyridinoline crosslinks, which are unique to bone (Hanson et al., 1992). Bone-forming osteoblasts synthesize a number of other proteins that are incorporated into the bone matrix, including osteocalcin and osteonectin, which constitute $40 \%$ to $50 \%$ of the noncollagenous proteins of bone (Rodan et al. 1991). Osteocalcin (OC) is widely used as a marker for in vivo osteoblastic activity and bone formation (Gerdhem et al., 2004). Mice deficient in osteocalcin develop a phenotype characterized by higher bone mass and improved bone quality, suggesting that osteocalcin functions normally to limit bone formation without compromising mineralization (Ducy et al., 1996). Osteonectin may mediate deposition of hydroxyapatite and binds growth factors (Termine et al., 1981; Delany et al., 1998). Mice deficient in osteonectin exhibit decreased osteoclast and osteoblast numbers and reduced bone remodeling suggesting that under normal conditions osteonectin may play a role in the birth or survival of these cells (Delany et al., 2000). A number of other minor proteins such as osteopontin, bone sialoprotein, fibronectin, vitronectin, and thrombospondin serve as attachment factors that interact with integrins (Grzesik et al., 1994). In addition to being the cells that produce the osteoid matrix, mature osteoblasts are essential for its 
mineralization, the process whereby deposition of hydroxyapatite crystals occurs (Hessle et al., 2002). Osteoblasts are thought to regulate the local concentrations of calcium and phosphate in such a way as to promote formation of hydroxyapatite crystals (Boskey, 1996; Boskey, 1998). Mineralization of the matrix increases the density of bone by displacing water, but does not alter its volume (Robinson et al., 1957; Neuman et al., 1958). Osteoblasts express very high amounts of alkaline phosphatase, which is anchored to the outer surface of the plasma membrane (Stein et al., 1993). Alkaline phosphatase has been long thought to play a role in bone mineralization. Consistent with this, deficiency of alkaline phosphatase due to genetic defects leads to a condition hypophosphatasia characterized by defective bone mineralization (Whyte, 1994; Wennberg et al., 2000). However, the precise mechanism of mineralization and the exact role of alkaline phosphatase in this process remain ambiguous.

Mature osteoclasts are usually large (50 to $100 \mu \mathrm{m}$ diameter), multinucleated cells with abundant mitochondria, numerous lysosomes, and free ribosomes. They are usually found in contact with a calcified bone surface and within lacunae that are the result of their own resorptive activity. Their most remarkable morphological feature is the ruffled border, a complex system of finger-shaped projections of the membrane, the function of which is to support the resorption of the calcified bone matrix (Roodman, 1996; Boskey, 1998). This structure is completely surrounded by another specialized area, called the clear zone. The clear zone delineates the area of attachment of the osteoclast to the bone surface and seals off a distinct area of the bone surface, essentially forming a secondary lysosome, that lies immediately 
underneath the osteoclast, that will be acidified and excavated. The ability of the clear zone to seal off this area of bone surface allows the formation of an acidic microenvironment suitable for the operation of the resorptive apparatus.

Acidification of the secondary lysosome is created by the action of an ATPdriven proton pump located in the ruffled border membrane. The mineral component of the matrix is dissolved in the acidic environment of the resorption site. The protein components of the matrix, mainly collagen, are degraded by matrix metalloproteinases and cathepsins that are secreted by the osteoclast into the area of bone resorption (Bossard et al., 1996). The degraded bone matrix components are endocytosed along the ruffled border within the resorption lacunae and transcytosed to the membrane area opposite the bone, where they are released (Salo et al., 1997). Active osteoclasts exhibit a characteristic polarity, that is, the nuclei of the osteoclasts are typically located in the part of the cell most removed from the bone surface and are interconnected by cytoskeletal proteins (Watanabe et al., 1995). Another characteristic of osteoclasts is the presence of high amounts of the phosphohydrolase enzyme, tartrate-resistant acid phosphatase (TRAPase). This aspect is widely used as marker for osteoclasts in bone specimens (Udagawa et al., 1990; Hayman et al., 1996).

Some mature osteoblasts are ultimately buried within refilled lacunae of mineralized matrix, and these buried cells are responsible for maintainence of matrix (Buckwalter et al., 1996). These cells are the osteocytes and are characterized by a striking stellate morphology, resembling the dendritic network of the nervous system (Marotti et al., 1990; Nijweide et al., 1996). Osteocytes are regularly spaced 
throughout the mineralized matrix and communicate with each other and with osteoblasts, which in turn communicate with cells of the bone marrow stroma (Fig. 1.). A syncytium extends from the entombed osteocytes all the way to the blood

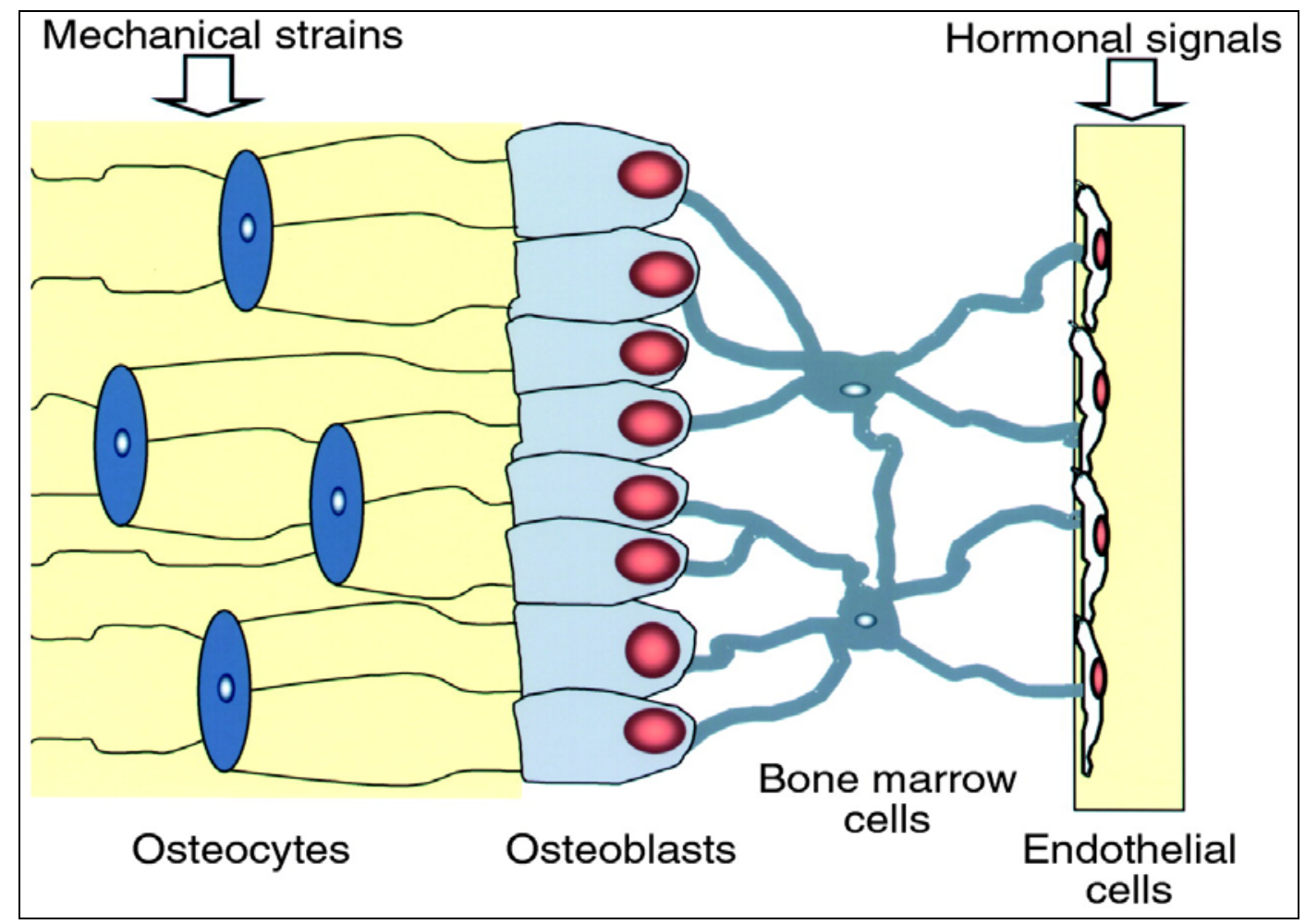

Figure 1. Functional syncytium comprising osteocytes, osteoblasts, bone marrow stromal cells, and endothelial cells. [Adapted from Journal of Clinical Investigation 104:1363-1374, 1999.]

vessel wall (Marotti et al., 1996). Consequenly, the strategic location of osteocytes makes them excellent candidates for mechanosensory cells able to detect the need for bone augmentation or reduction during functional adaptation of the skeleton, and the need for repair of microdamage. The disruption of the osteocyte network would be likely to increase bone fragility (Weinstein et al., 1998; Tomkinson et al., 1998). Bone lining cells are flat, elongated, dormant cells that cover bone surfaces that are undergoing neither bone formation nor resorption (Parfitt, 1994). 
During development and growth, the skeleton is sculpted to achieve its shape and size by the removal of bone from one site and deposition at a different one; this process is called modeling. Once the skeleton has reached maturity, regeneration continues in the form of a periodic replacement of old bone with new at the same location (Frost, 1973). This process is called remodeling and is responsible for the complete renewal of the adult skeleton every 10 years. The purpose of remodeling in the adult skeleton is not entirely clear, although in bones that are load bearing remodeling most likely serves to repair fatigue damage and to prevent excessive aging and its consequences. Therefore, the most likely function of bone remodeling is to prevent the accumulation of old or damaged bone.

Removal of bone i.e., resorption, is the task of osteoclasts, while formation of new bone is the function of osteoblasts. Bone resorption and bone formation are not independently regulated processes (Parfitt, 1984). In the uninjured adult skeleton, all osteoclasts and osteoblasts belong to a unique transitory structure, known as a basic multicellular unit or BMU (Parfitt, 1994). Although during modeling one cannot distinguish anatomical units analogous to the BMU by itself, sculpting of the growing skeleton requires spatial and sequential orchestration of the destination of osteoblasts and osteoclasts, although with different rules and coordinates to those operating in the BMU of the remodeling skeleton. The BMU in cortical bone is approximately $1-2 \mathrm{~mm}$ long and $0.2-0.4 \mathrm{~mm}$ wide, comprises a team of osteoclasts in the front, a team of osteoblasts in the back, a central vascular capillary, a nerve supply, and associated connective tissue (Parfitt, 1994). In healthy human adults, it is estimated that 3-4 million BMUs are initiated per year and about 1 million are 
operating at any moment. Each BMU begins at a particular place and time (origination) and advances toward a target, which is a region of bone in need of replacement, and for a variable distance beyond its target (progression) and eventually comes to rest (termination) (Parfitt, 1996). Osteoclasts adhere to bone and subsequently remove it by acidification and proteolytic digestion. As the BMU advances, osteoclasts leave the resorption site and osteoblasts move in to cover the excavated area and begin the process of new bone formation by secreting osteoid, which is eventually mineralized into new bone.

Table 1. Vital statistics of adult bone remodeling (Parfitt, 1994).

- Lifespan of BMU - 6-9 months

- Speed - $25 \mu \mathrm{m} /$ day

- Bone volume replaced by a single BMU - $0.025 \mathrm{~mm}^{3}$

- Lifespan of osteoclasts - 2 weeks

- Lifespan of osteoblasts (active) - 3 months

- Interval between successive remodeling events at the same location - 2-5 years.

- Rate of turnover of whole skeleton - $10 \%$ per year

The lifespan of the BMU is 6-9 months, which is much longer than the lifetime of its constituent cells (Table 1). As a result, a continuous supply of new osteoclasts and osteoblasts derived from their respective progenitors in the bone marrow is essential for the origination of BMUs and their progression on the bone surface.

Consequently, the balance between the supply of new cells and their lifespan are key determinants of the number of either cell type in the BMU and the work performed by each type of cells which is significant for the maintenance of bone homeostasis.

"Remodeling" of bone begins early in fetal life, and once the skeleton is fully formed in young adults, most of the skeletal metabolic activity is in this form 
(Eriksen, 1986; Erlebacher et al., 1995; Reddi, 1997). The bone remodeling cycle involves a series of highly regulated steps (Fig. 2.) that depend on the interactions of the osteoblastic cells and the osteoclastic cells (Raisz et al., 1983; Raisz, 1999). The initial "activation" stage involves the interaction of osteoclast and osteoblast

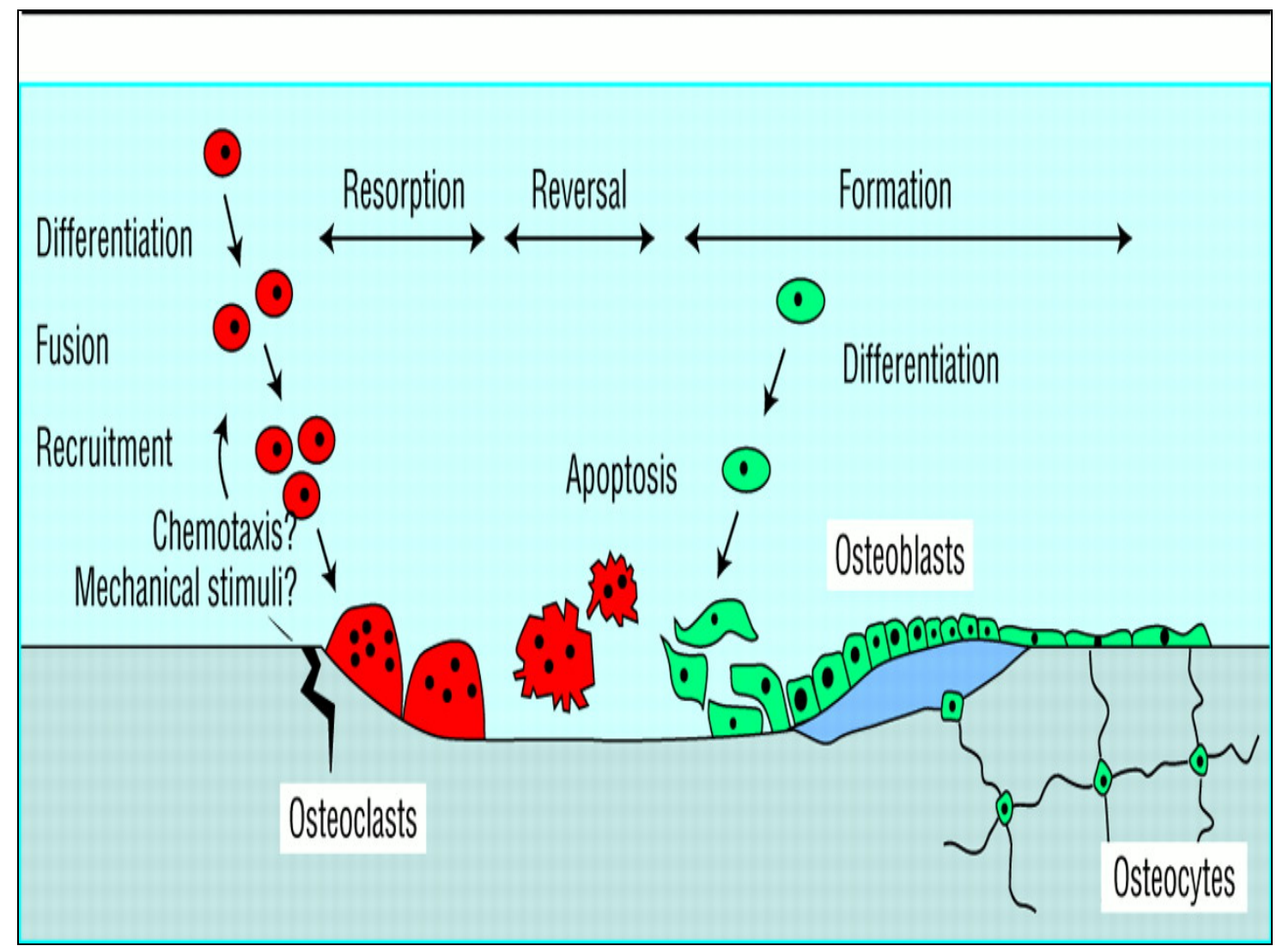

Fig. 2. Bone remodeling: Remodeling begins with attraction of osteoclasts to the target site, probably triggered by mechanical stimuli or release of chemotactic substances from areas of microdamage in bone. Mature osteoclasts remove bone during the phase of bone resorption. After resorption is complete, osteoclasts undergo apoptosis during the reversal phase, and bone formation begins as osteoblasts are recruited to the site. Some osteoblasts become trapped within bone matrix and differentiate to form osteocytes, which act as sensors of mechanical strain in bone (Ralston, 1997).

precursor cells leading to the differentiation, migration, and fusion of mononuclear cells to produce the large, multinucleated osteoclasts. These osteoclast cells attach to 
the mineralized bone surface and initiate resorption by the secretion of hydrogen ions and lysosomal enzymes, particularly cathepsins, which can degrade all the components of bone matrix, including collagen, at low $\mathrm{pH}$. Osteoclastic resorption produces irregular, scalloped cavities called lacunae in the trabecular bone surface, and called cylindrical Haversian canals in cortical bone. Once the osteoclasts have completed their work of bone removal, there is a "reversal" phase during which mononuclear cells, possibly of the macrophage lineage, are seen on the bone surface. The events during this stage are not well understood, but they may involve further degradation of collagen, the deposition of proteoglycans to form the so-called cement line, and the release of growth factors to initiate the formation phase. During the final "formation" phase of the remodeling cycle, the cavity created by resorption can be completely filled in by successive layers of osteoblasts, deposition of mineralizable matrix.

Most simply put, the challenges of understanding the complexities of skeletal modeling and remodeling, are illustrated by the influences that osteoblasts have on osteoclasts and vice versa (Marks et al., 1988; Mundy, 1994). The development and differentiation of osteoblasts and osteoclasts, and consequently bone remodeling, is controlled by growth factors and cytokines produced in the bone and bone marrow microenvironment (Manolagas, 1998). Several systemic hormones, as well as mechanical signals, also exert potent effects on osteoclast and osteoblast development and differentiation (Raisz, 1993; Mosley, 2000).

The metabolic functions of the skeleton are served in large part by two major calcium-regulating systemic hormones, parathyroid hormone (PTH) (Dempster et al., 
1993; Hodsman et al., 1997) and 1,25-dihydroxy vitamin $\mathrm{D}_{3}$ (Li et al., 1998). PTH regulates serum calcium concentration. It is a potent stimulator of bone resorption and has biphasic effects on bone formation. There is an acute inhibition of collagen synthesis with high concentrations of PTH, but prolonged intermittent administration of this hormone produces increased bone formation, a property for which it is being explored clinically as an anabolic agent (Dempster et al., 1993). 1,25-dihydroxy vitamin $\mathrm{D}_{3}$ has its greatest effect on intestinal calcium and phosphate absorption, but has direct effects on bone and other tissues ( $\mathrm{Li}$ et al., 1998). It is probably critical for the differentiation of osteoblasts and osteoclasts and can stimulate bone resorption and formation under some experimental conditions (Norman, 1992). A third hormone, calcitonin, which can inhibit bone resorption, may be important in skeletal development but appears to play little role in physiologic calcium regulation in adult humans (Whitfield et al., 2002; Doggrell, 2003; Stepan et al., 2003).

The most significant systemic hormone in regards to maintaining normal bone turnover is estrogen (Pacifici, 1996; Pacifici, 1998). Estrogen deficiency leads to an increase in bone remodeling in which resorption outstrips formation and bone mass decreases. This can be observed not only in postmenopausal women, but also in men with defects either in the estrogen receptor or in the synthesis of estrogen from testosterone (Bilezikian et al., 1998). The mechanisms by which estrogen regulates bone turnover are still not well understood, although studies in animals suggest that estrogen acts by changing either the production or activity of local factors that regulate osteoblast and osteoclast precursors (Lorenzo, 1992; Pacifici, 1998). Estrogen treatment produces a decrease in both formation and resorption of 
bone associated with decreased remodeling, but overall increases bone mass. This increase may simply be a result of the filling in of the resorption space.

There is a concept that there must be local factors that also regulate bone remodeling (McLeod et al., 1998). The identification of these local factors has occurred only during the last 30 years. Among the first of the local factors to be identified were cytokines. Originally these "osteoclast-activating factors", which could be produced by inflammatory cells, particularly macrophages, were implicated in the local bone loss associated with periodontal disease and inflammatory arthritis (Lorenzo, 1992). At about the same time prostaglandins, particularly prostaglandin $E_{2}$, were shown to be potent stimulators of bone resorption that could also be important in inflammatory bone loss (Kawaguchi et al., 1995).

A large number of cytokines and growth factors that can affect bone cell functions have now been identified. The only factors capable of initiating osteoblastogenesis from uncommitted progenitors are bone morphogenetic proteins (BMPs) (Rosen et al., 1996; Sakou, 1998). BMPs have been long implicated in skeletal development during embryonic life and fracture healing. More recently, it has become apparent that BMPs, and in particular BMP-2 and BMP-4, also initiate the commitment of mesenchymal precursors of the adult bone marrow to the osteoblastic lineage (Abe et al., 2000). Other factors such as transforming growth factor- $\beta$ (TGF- $\beta$ ), platelet-derived growth factor (PDGF), insulin-like growth factors (IGFs), and members of the fibroblast growth factor (FGF) family can all stimulate osteoblast differentiation (Bonewald et al., Hakeda et al., 1996; Inui et al., 1998; Mills et al., 1997). However, although TGF- $\beta$, PDGF, FGF, and IGFs are able to 
influence the replication and differentiation of committed osteoblast progenitors toward the osteoblastic lineage, they cannot induce osteoblast differentiation from uncommitted progenitor cells.

A large group of cytokines and colony-stimulating factors that are involved in hematopoiesis also stimulate osteoclast development (Takahashi et al., 1991; Fujikawa et al., 2001). This group includes several interleukins (IL-1, IL-3, IL-6, IL11), tumor necrosis factor- $\alpha$ (TNF- $\alpha$ ), granulocyte macrophage-colony stimulating factor (GM-CSF) and M-CSF. As opposed to the above listed cytokines that stimulate osteoclast development, IL-10, IL-12 and IL-18 inhibit osteoclast development (Horwood et al., 2001; Owens et al., 1996).

Recently, some of the proteins that are responsible for the interaction between cells of the osteoblastic and osteoclastic lineage have been identified. These proteins belong to the family of tumor necrosis factor receptors (Takahashi et al., 1999; Yasuda et al., 1999; Khosla, 2001). Osteoblast precursors express a molecule called TRANCE or RANKL, which can activate cells of the osteoclast lineage by interacting with a receptor called RANK (Receptor Activator of NF-kB) (Takahashi et al., 1999; Suda et al., 1999). A third molecule, osteoprotegerin (OPG), can be produced by cells of the osteoblast lineage or by other cells in the marrow (Gori et al., 2000). OPG acts as a decoy receptor for TRANCE, blocking its interaction with RANK and inhibiting osteoclast formation (Aubin et al., 2000; Hofbauer et al., 2000; Khosla, 2001). Recent studies have shown that knocking out the OPG gene in rodents produces severe osteoporosis characterized by excessive bone resorption (Kostenuik et al., 2001). 
Prostaglandin $\mathrm{E}_{2}\left(\mathrm{PGE}_{2}\right)$ was identified as a product of unstimulated and complement-stimulated fetal rat long bones (Klein et al., 1970, Raisz et al., 1979). Subsequently $\mathrm{PGA}_{2}, \mathrm{PGI}_{2}, \mathrm{PGD}_{2}, \mathrm{PGE}_{2}$, and $\mathrm{PGF}_{2 \alpha}$ were found in bone cultures (Klein et al., 1970). The discovery that $\mathrm{PGI}_{2}$ could be synthesized by the bone itself was of substantial interest, as its short half-life would be of less consequence if it was synthesized by cells on or immediately adjacent to the bone surface (Raisz et al., 1979).

There are four known $\mathrm{PGE}_{2}$ receptors, $\mathrm{EP}_{1-4}$ and one prostaglandin $\mathrm{F}_{2 \alpha}$ receptor in bone (Suda et al., 1996; Nemoto et al., 1995). Little is known about prostaglandin receptor functioning in bone cells, but there are indications that $\mathrm{PGE}_{2}$ stimulates osteoblastic differentiation in bone marrow cultures by activating the $\mathrm{EP}_{4}$ receptor, an effect that may involve recruitment of uncommitted osteogenic precursors (Weinreb et al., 1999). In addition, a role of $\mathrm{EP}_{4}$ in $\mathrm{PGE}_{2}$-induced osteoclast formation has been shown, suggesting a therapeutic potential of $\mathrm{EP}_{4}$ antagonists in some clinical conditions with accelerated bone resorption (Ono et al., 1998; Suzawa et al., 2000). The $\mathrm{EP}_{1}$ subtype of $\mathrm{PGE}_{2}$ receptor plays a role in the autoamplification of $\mathrm{PGE}_{2}$ (Funk et al., 1993; Suda et al., 1998; Suda et al. 2000). The autoamplification of $\mathrm{PGE}_{2}$ production is considered to be important in elongating the otherwise short-lived $\mathrm{PGE}_{2}$ action in certain physiological conditions such as mechanical stress and fracture healing, as well as the pathological inflammatory bone loss (Suda et al., 1998). A role for $\mathrm{EP}_{2}$ receptor has been suggested in rapidly growing skeletal tissue (Nemoto et al., 1997). 
Prostaglandins are abundant in bone and are produced by cells of the osteoblastic lineage (Raisz et al., 1993; Okada et al., 2003). They are complex regulators of bone metabolism, being potent stimulators of bone resorption in organ culture (Klein et al., 1970; Kawaguchi et al., 1995; Raisz, 1999), but inhibiting bone resorption by isolated osteoclasts (Raisz, 1995; Kawaguchi et al., 1995). This inhibitory effect was demonstrated in isolated osteoclasts but is difficult to exhibit when osteoblasts are also present. $\mathrm{PGE}_{2}$ can mediate resorptive responses to cytokines and growth factors in bone (Miyaura et al., 2000; Sakuma et al., 2000).

Although the effects of prostaglandins on bone resorption have been studied to a much greater extent than those on bone formation, it seems likely that their effects on bone formation will be of at least equal importance in regulation of bone metabolism (Vrotsos et al., 2003). As with resorption, prostaglandins can also stimulate and inhibit bone formation. High concentrations of prostaglandins can inhibit collagen synthesis and reduce procollagen (I) mRNA levels in bone (Raisz et al., 1993). The stimulatory effect can be observed in vitro either at low concentrations or in the presence of cortisol and is probably indirect effect (Flanagan et al., 1994; Gronowicz et al., 1994). Although the anabolic effect of prostaglandins is indirect, it is a potent effect and may predominate in vivo (Jee et al., 1985; Jee et al., 1987; Mori et al., 1990; Miller et al., 1994).

Prostaglandins are formed by most cells in our bodies and act as autocrine and paracrine lipid mediators (i.e., signal at or immediately adjacent to their site of synthesis) (Samuelsson, 1983; Six et al., 2000). They are not stored but are synthesized de novo from membrane-released arachidonic acid when cells are 
activated by mechanical trauma or by specific cytokine, growth factor, and other stimuli (e.g., collagen and adenosine diphosphate in platelets, bradykinin and thrombin in endothelium). A host of enzymes regulate cellular levels of arachidonic acid, keeping it esterified until mobilized by phospholipase $\mathrm{A}_{2}\left(\mathrm{PLA}_{2}\right)$. The control of arachidonic acid release from membranes has undergone several paradigm shifts in recent years with the continuing identification of new PLA $A_{2}$ members (Six et al., 2000). Despite this, type IV cytosolic PLA (cPLA $_{2}$ ) remains the key player for eicosanoid production.

The levels of free arachidonic acid are normally very low since the liberated fatty acid is rapidly metabolized (Samuelsson, 1987). Free arachidonic acid is a substrate for two distinctively different enzymatic pathways, one leading to the synthesis of PGs, the other to the hydroperoxy- and hydroxy-eicosatetraenoic acids referred to as HPETEs and HETEs, respectively (Ford-Hutchinson, 1990). The two pathways have in common the insertion of molecular oxygen into the fatty acid, although PGs have an additional cyclopentane ring. Lipoxygenases (LOXs) are a family of enzymes that catalyze the incorporation of molecular oxygen into polyunsaturated fatty acids at specific positions to form active metabolites such as HETEs. Three major LOXs have been characterized in mammals and designated as 5-, 12-, and 15-LOX, that produce 5(S)-, 12(S)-, 15(S)- hydroperoxides (hydroxyperoxyiecosatetranoic acids, HPETEs) respectively, products that are reduced to 5(S)-, 12(S)-, 15(S)- hydroxyeicosatetranoic acids (HETEs). The three enzymes are known mainly from the blood cells in which they are robustly expressed—the 5S-lipoxygenase in leukocytes, the $12 S$-lipoxygenase in platelets, 
and the 15S-lipoxygenase in reticulocytes, macrophages and eosinophils (Brash et al., 1997). Nevertheless selective expression is well documented in other tissues, for example, both the 12S- and 15S-lipoxygenases are detected in skin (Nugteren et al., 1987; Takahashi et al., 1993). 12-lipoxygenase generates from arachidonic acid the bioactive lipid 12-hydroxyeicosatetranoic acid (12-HETE), which has been shown to promote growth in chinese hamster ovary fibroblasts (Wen et al., 2000; Limor et al., 2001), and the proliferation of pancreatic cancer cells (Brash et al., 1997). Studies have suggested that the HETEs may activate osteoclasts and increase bone resorption (Meghji et al., 1988). However, very little is still known about the exact roles the HETEs play as regulators of bone remodeling.

Arachidonic acid released by the cytosolic isoform of the PLA $\mathrm{A}_{2}\left(\mathrm{CPLA}_{2}\right)$ is alternatively presented to prostaglandin $\mathrm{H}$ synthase (referred to colloquially as $\mathrm{COX}$ for cyclooxygenase) pathway and the fatty acid is then metabolized into an intermediate prostaglandin, $\mathrm{PGH}_{2}$. PGHS exists as two isoforms referred to as PGHS-1 (COX-1) and PGHS-2 (COX-2) (Smith et al., 2000). In simple terms, COX-1 is the enzyme responsible for basal, constitutive prostaglandin synthesis, whereas COX-2 is important in various inflammatory and "induced" conditions (Crofford, 1997; Vane et al., 1998). The constitutive COX-1 is mainly utilized in immediate $\mathrm{PGH}_{2}$ biosynthesis, which occurs within several minutes after stimulation with $\mathrm{Ca}^{2+}$ mobilizers, whereas the inducible COX-2 mediates delayed $\mathrm{PGH}_{2}$ biosynthesis, which lasts for several hours following proinflammatory stimuli. COX-1 and COX-2 have been reported to exhibit subtle differences in AA requirements, that is COX-2 is favored over COX-1 at low AA concentrations 
(Murakami et al., 1999), and differences in their subcellular localizations (Vane et al., 1998). The COX enzymes are monotypically inserted into the ER and nuclear membrane with the substrate-binding pocket precisely oriented to take up released arachidonic acid. The crystal structures of COX-1 and COX-2 are remarkably similar, with one notable amino acid difference that leads to a larger "side-pocket" for substrate access in COX-2 (Smith et al., 2000).

Vane and coworkers found that the analgesic, antipyretic and antiinflammatory properties of acetylsalicylate (aspirin) were based on the inhibition of prostaglandin synthesis (Vane, 1971). Vane showed that the acidic antiinflammatory analgesics decreased pro-inflammatory prostaglandin concentrations by inhibiting cyclooxygenases. The cyclooxygenase activity of PGH synthase is the target site of aspirin, ibuprofen and related nonsteroidal anti-inflammatory drugs (NSAIDs) (Abramson et al., 1985; Higgs et al., 1987); most NSAIDs, including aspirin, are competitive inhibitors of COX-1 (Kulmacz et al., 1985). NSAIDs, which possess analgesic, anti-inflammatory and antipyretic properties, are a heterogeneous group of substances without any uniform chemical properties, but nevertheless share the same therapeutic and side effects. However, the selective blockade of the COX-2 isoform should lead to the inhibition of inflammation and pain without impeding the COX-1-dependent prostaglandin production (Vane, 1994). This hypothesis led to an intensive worldwide search for selective COX-2 inhibitors; since 1999 rofecoxib (Vioxx ${ }^{\circledR}$ ) and celecoxib (Celebrex $\left.{ }^{\circledR}\right)$ have been available in the markets.

Downstream of the cyclooxygenases, the product $\mathrm{PGH}_{2}$ can be further metabolized into various important eicosanoids, specifically $\mathrm{PGE}_{2}, \mathrm{PGF}_{2 \alpha}, \mathrm{PGD}_{2}$, 
$\mathrm{PGI}_{2}$, and thromboxane $\mathrm{A}_{2}$ (Smith, 1992) (Fig. 3.). The coupling of $\mathrm{PGH}_{2}$ synthesis and metabolism by down stream enzymes is intricately coordinated in a cell-specific fashion. Thromboxane synthase is found in platelets and macrophages, prostacyclin

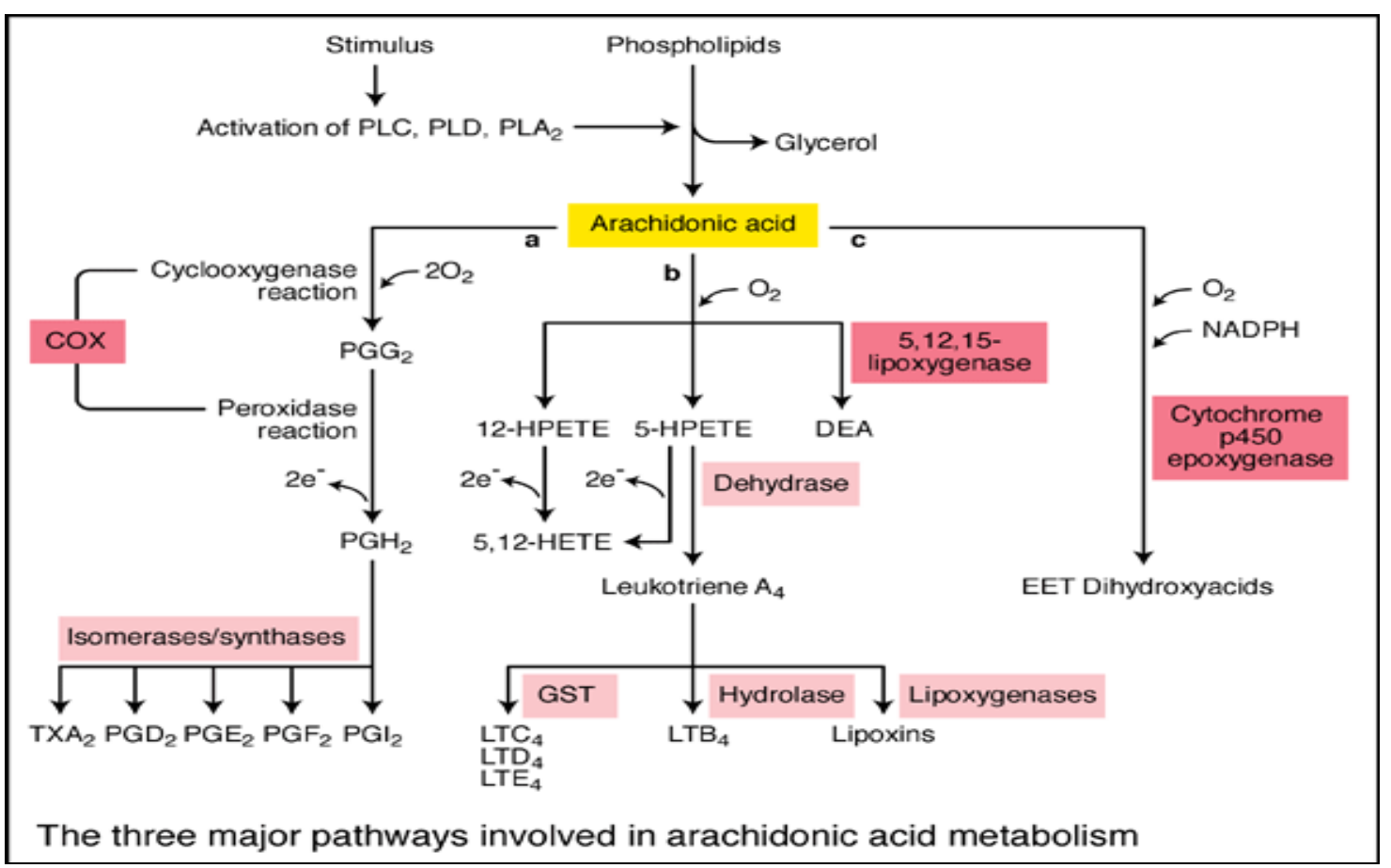

Fig. 3. The three major pathways involved in arachidonic acid metabolism .

(a) The cyclooxygenase (COX) pathway results in the formation of prostaglandin G2 (PGG2) from arachidonic acid by a cyclooxygenase reaction. In a subsequent peroxidase reaction, $P G G 2$ undergoes a two-electron reduction to PGH2. Both of these reactions are catalysed by COX (prostaglandin synthase H). PGG2 serves as a substrate for cell-specific isomerases and synthases, producing other eicosanoids.

(b) The lipoxygenase pathway forms hydroperoxyeicosatetraenoic acids (HPETEs) and dihydroxyeicosatetraenoic acid (DEA) by lipoxygenase and subsequently converts these to (1) hydroxyeicosatetraenoic acids (HETEs) by peroxidases, (2) leukotrienes (e.g. LTC4) by hydrase and glutathione S-transferase (GST), and (3) lipoxins by lipoxygenases. (c) The epoxygenase pathway forms epoxyeicosatrienoic acid (EET) and dihydroxyacids by cytochrome p450 epoxygenase.

synthase is found in endothelial cells, both of which belong to the cytochrome P-450 family and are reportedly localized in the endoplasmic reticulum (ER) and perinuclear membranes (Walsh, 1989; Ramos et al., 1995; Walsh, 2004). PGF $_{2 \alpha}$ synthase in lung and liver are cytosolic proteins with high homology to the aldo- 
reductase family (Suzuki et al., 1999; Suzuki-Yamamoto et al., 1999; SuzukiYamamoto et al., 2000). $\mathrm{PGD}_{2}$ synthases, which isomerize $\mathrm{PGH}_{2}$ to $\mathrm{PGD}_{2}$, occur in two distinct forms, the haemopoietic PGDS (H-PGDS) is the key enzyme for production of the $\mathrm{D}$ series of prostanoids in the immune system and mast cells (Kanaoka et al., 1997), and the lipocalin-type PGDS (L-PGDS) that is abundantly present in the central nervous system (Urade et al., 2000; Urade et al., 2002).

Two proteins that exhibit PGE $_{2}$ synthase (PGES) activity have been identified to date; they are the constitutive cytosolic PGES (cPGES), which is identical to p23 (Nakatani et al., 2002), and the inducible, perinuclear membaranebound PGES (mPGES) (Murakami et al., 2002). Thus, $\mathrm{PGE}_{2}$ synthase activity is present in both cytosolic and membrane fraction of cells, and the optimal catalytic activity of each enzyme require glutathione (Tanioka et al., 2000; Nakatani et al., 2002). Cytosolic PGES (cPGES), a GSH-requiring enzyme constitutively expressed in a wide variety of cells, is functionally linked to COX-1, not COX-2, to promote immediate $\mathrm{PGE}_{2}$ production (Tanioka et al., 2000). The expression of mPGES is strongly induced by proinflammatory stimuli in vitro and at inflamed sites in vivo and is down regulated by anti-inflammatory glucocorticoids (Stichtenoth et al., 2001). mPGE 2 synthase activity can also be induced by proinflammatory stimuli in leukocytes (Fournier et al., 1997). Induction of mPGES-1 expression has also been observed in various systems in which COX-2-derived $\mathrm{PGE}_{2}$ has been implicated to play a critical role, such as inflammation, fever, pain, female reproduction, tissue repair and cancer (Jakobsson et al., 1999; Murakami et al., 2000; Claveau et al., 2003; Thoren et al., 2003; Kamei et al., 2003). 
The present studies were undertaken to examine the effects of TNF- $\alpha$ and TGF- $\beta$, known mediators of osteoblast biology and bone remodeling, on PG and HETE biosynthesis in the human osteoblast-like (hOB) cell model system. It is possible that modulation of $\mathrm{PGE}_{2}$ synthesis by cytokines in various cells and tissues may also have resulted, in part, from increased amounts of PGE 2 synthases (cPGES and mPGES), which are downstream of COX enzymes in the arachidonic acid metabolic pathway for $\mathrm{PGE}_{2}$ production. To examine this possibility transcripts for cPGES and mPGES were detected in hOB cells, by reverse-transcriptase polymerase chain reaction using specific primers for human cPGES and mPGES.

Even though no cell culture model can exactly duplicate in vivo physiology, non-transformed cells approximate normal biology to a greater extent than do cancerous cells (Sporn et al., 1980). Therefore, in order to best mimic in vivo bone biology, all of the experiments made use of cultured hOB cells. hOB cells are grown from femoral bone explants and cultured in T-175 flasks, passaged twice, and then used for experimentation. These hOB-like cells represent a fairly mature osteoblast phenotype and respond appropriately to hormone and cytokine treatments (Robey and Termine 1985; Keeting et al., 1991). The use of hOB cells obtained from human bone explants avoids the problems of understanding and application of data acquired from whole animal models, or from animal derived bone cells to human bone. However, as with the other model systems there are limitations attendant with this model system. For example, primary human cell cultures are derived from a heterogeneous population, thus interstrain variations in characterstics and responses of the cells can sometimes be large, thereby making analysis challenging. 
Furthermore, hOB cells have a limited life span and they grow slowly in culture limiting the variables being tested on a single strain of cells. The difficulties associated with studying such cells are counterbalanced with their suitability as a model system representing authentic human osteoblasts.

The objectives of these studies were focused to: 1) describe the spectrum of PGs and HETEs produced by hOB cells under basal and cytokine-stimulated conditions and 2) to determine steady-state mRNA levels of cPGES or mPGES which could lead to increased $\mathrm{PGE}_{2}$ production. 


\section{MATERIALS AND METHODS}

\section{Experimental Subjects}

Cancellous bone explants were obtained as surgical waste generated from the femoral head during routine bone grafting procedures. The harvest of this waste material following informed consent was approved by the West Virginia University Internal Review Board. Patient records were evaluated, and explants were not taken from patients with diagnosed osteoporosis or from patients presenting with endocrine disorders known to affect bone. Bone explants used in the EIA experiments were from 3 men aged 61 to 77 (median age of 64), and from 3 women aged 59 to 84 (median age of 80). Bone explants used in cPGES RT-PCR studies were from 3 women aged 23 to 85 (median age of 48) and 1 man aged 64. Bone explants used in mPGES RT-PCR studies was from 2 men aged 75 and 64, 2 women aged 23 and 48. Bone explants used in LOX RT-PCR studies were from 3 men aged 61 to 75 (median age of 68).

\section{hOB Cell Cultures}

Cancellous bone explants were prepared and placed into culture according to the method developed by Robey and Termine (1985), as previously described by Cissel et al. (1996). The essential elements of this method include stripping the explants in a 2 hour collagenase ( $1 \mathrm{mg} / \mathrm{ml}$; Gibco, Grand Island, NY) digestion after which the explants were placed in a calcium-free, phenol red-free mixture of DMEM: Ham’s F12K (1:1) (Biofluids, Rockville, MD) supplemented to 8\% heatinactivated fetal calf serum (FCS; Gibco). These culture methods yield nearly 
homogeneous cell cultures that display multiple aspects of the mature osteoblast phenotype (Cissel et al. 1996, Borke et al., 1988). The hOB cell phenotype is stable through at least 4 passages (Marie, 1994). All experiments described in this work used hOB cells subcultured in $2^{\text {nd }}$ or $3^{\text {rd }}$ passage.

\section{Reagents}

Recombinant human tumor necrosis factor- $\alpha$ and recombinant human transforming growth factor- $\beta$ were purchased from R\&D Systems (Minneapolis, MN). IL-1 $\beta$ and IL-3 were purchased from BioRad. Stock solutions of each were prepared according to the supplier's instructions, and stored at $-20^{\circ} \mathrm{C}$ for no more than 4 months. $\mathrm{PGE}_{2}$, 6-keto $\mathrm{PGF}_{1 \alpha}, \mathrm{PGF}_{2 \alpha}, \mathrm{PGD}_{2}, \mathrm{TXA}_{2}$ and 15-HETEMonoclonal Enzyme Immunoassay (EIA) Kits were obtained from Cayman Chemical Co. (Ann Arbor, MI). RT-PCR One-Step kits were obtained from Invitrogen (Carlsbad, CA). Other chemicals and reagents used were of the highest quality grade available. Oligonucleotide primers for human glyceraldehyde-3phosphate dehydrogenase (GAPdH), cPGES, mPGES and 15-Lipoxygenase type II were purchased from Invitrogen. The oligonucleotide primers used were as follows: mPGES, forward 5'-ATGCCTGCCCACAGCCTG-3', and reverse 5'TCACAGGTGGCGGGCCGC-3'; for cPGES, forward 5'ATGCAGCCTGCTTCTGCA-3', and reverse 5'-TTACTCCAGATCTGGCAT-3' (Stichtenoth et al., 2001); for 15-lipoxygenase type II (Tang et al., 2002): forward 5'AACTCACCCCCACCACCATACACA-3’ and reverse 5’TTCCCGCCTCCATCTCCCAAAGT-3', primers that amplify a 351 bp fragment 
and cover nucleotides 2234-2584 in the 3'-UTR (3'-untranslated region).

Amplification specificity of cPGES, mPGES, 15-lipoxygenase type II and GAPdH sequences was assured by sequencing the subcloned gel purified PCR products from our experiments (Univ. California-Davis Sequencing Laboratory).

\section{hOB Cell Incubations}

hOB cells were subcultured at 50,000 cells/well into 24-well plates (EIAs) or at 150,000 cells/well into 12-well plates (RNA assays) in medium supplemented to 1 $\mathrm{mM}$ calcium and 10\% (v/v) FCS (see flow chart below). In all experiments the calcium concentration of the media was thereafter maintained at $1 \mathrm{mM}$.

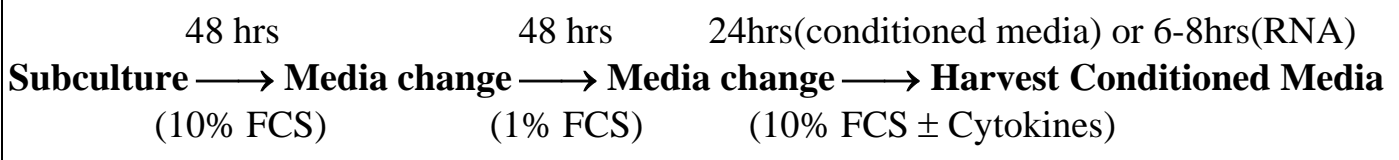

Forty-eight hours after subculturing, media were replaced and the FCS was reduced to $1 \%$ for an additional 48 hours. Media were changed and the experimental manipulations were initiated by the addition of 20 nM TNF- $\alpha, 40$ pM TGF- $\beta$, TNF$\alpha$ plus TGF- $\beta$, TNF- $\alpha$ and TGF- $\beta$ plus ibuprofen, or vehicle for 24 -hours when harvesting conditioned media for EIA studies, or for 6-8 hours when harvesting total RNA. For 15-lipoxygenase type II RT-PCR studies, hOB cells were exposed to growth factors and cytokines at final concentrations as follows: TGF- $\beta$ at 40 pM; TNF- $\alpha$ at 400 pM alone, and in combination with TGF- $\beta$; IL-1 $\beta$ and IL-3 at 300 pM. 
These concentrations of TGF- $\beta$, TNF- $\alpha$, and IL- $1 \beta$ elicit their maximum effects on hOB cell $\mathrm{PGE}_{2}$ production (Xu et al., 1997). The concentration of IL-3 was based on the literature (Li et al., 1992).

\section{Immunochemical Assays for PGs}

hOB cells were subcultured in 24-well plates at a density of 50,000 cells/well. After the 48 hour attachment, the cells were placed in 1\% FCS for an additional 48 hours. Following the replacement of 1\% with 10\% FCS, cytokines, or vehicle, were added to the media as described. After treatment, the conditioned media were collected and were stored at $-80^{\circ} \mathrm{C}$ until assayed. PGE 2 , 6-keto $\mathrm{PGF}_{1 \alpha}$, $\mathrm{PGF}_{2 \alpha}, \mathrm{PGD}_{2}, \mathrm{TXA}_{2}$ and 15-HETE were measured in hOB cell conditioned media using specific EIA kits according to the supplier's instructions (Cayman Chemical). Each sample was assayed at least two dilutions and performed in duplicate. The detection limit for different prostaglandins were PGE $_{2} 15$ pg/ml, 6-keto PGF ${ }_{1 \alpha} 11$ $\mathrm{pg} / \mathrm{ml}, \mathrm{PGF}_{2 \alpha} 9 \mathrm{pg} / \mathrm{ml}, \mathrm{PGD}_{2} 3.1 \mathrm{pg} / \mathrm{ml}, \mathrm{TXA}_{2} 11 \mathrm{pg} / \mathrm{ml}$ and 15-HETE $170 \mathrm{pg} / \mathrm{ml}$ at

$80 \% \mathrm{~B} / \mathrm{B}_{0}$. Briefly, the assay is based upon the competition between PG or 15-HETE in the sample or standards and the respective PG or 15-HETE acetylcholine-esterase conjugate (tracer) for a limited amount of specific monoclonal antibody.

The limits of detection at $\left(80 \% \mathrm{~B} / \mathrm{B}_{0}\right)$ for different kits were as follows: Prostaglandin $\mathrm{E}_{2}-15 \mathrm{pg} / \mathrm{ml}, 6$ keto-Prostaglandin $\mathrm{F}_{1 \alpha}-11 \mathrm{pg} / \mathrm{ml}$, Prostaglandin $\mathrm{F}_{2 \alpha}$ $9 \mathrm{pg} / \mathrm{ml}$, Prostaglandin $\mathrm{D}_{2}-3.1 \mathrm{pg} / \mathrm{ml}$, Thromboxane $\mathrm{B}_{2}-11 \mathrm{pg} / \mathrm{ml}$ and 15-HETE $170 \mathrm{pg} / \mathrm{ml}$. The intra- and interassay coefficient of variations (CVs) for: $\mathrm{PGE}_{2}$ were $4.8 \%$ and $13.2 \%$ respectively, 6 -ketoPGF ${ }_{1 x}$ were $5.2 \%$ and $12.0 \%$ respectively, 
$\mathrm{PGF}_{2 x}$ were $4.4 \%$ and $12.9 \%$ respectively, $\mathrm{PGD}_{2}$ were $5.2 \%$ and $2.9 \%$ respectively, 15-HETE were $5.7 \%$ and $8.7 \%$ respectively.

\section{Reverse Transcription-Polymerase Chain Reaction (RT-PCR)}

RT-PCR analysis was preferred over Northern blotting to assess specific mRNA levels due to cell culture limitations and the high costs associated with TNF treatments. hOB cells were subcultured at a density of 150,000 cells/well in 12-well plates in 10\% FCS medium. After 48 hours, media were changed to 1\% FCS for 48 hours. Following the replacement of $1 \%$ with $10 \%$ FCS, the cytokines were added to the media 6-8 hours before harvesting the cells for RNA preparations. Total RNA was isolated using the TRIZOL Reagent (Invitrogen) and DNAase treated. RNA yields were estimated by absorbance at $260 \mathrm{~nm}$, and the reverse transcriptions and amplifications were performed starting with 50 ng of total RNA per sample, using the RT-PCR One-Step kit according to the manufacturer's recommendations.

Thirty-five cycles of amplifications were performed for cPGES at $50^{\circ} \mathrm{C}, 32$ cycles for mPGES at $65^{\circ} \mathrm{C}, 35$ cycles for 15 -lipoxygenase type II at $65^{\circ} \mathrm{C}$ and 25 cycles for $\mathrm{GAPdH}$ at $55^{\circ} \mathrm{C}$, leaving each product in its linear range. Hybridization intensities in these experiments were determined using the BioRad Fluor-S ${ }^{\mathrm{TM}}$ MultiImager gel documentation system with their software. All data are presented as "Fold-basal" in which the band intensity of the treated specimens was compared with that of its respective control after correcting for concurrently amplified human GAPdH levels in the control and treated specimens. 


\section{Statistical Analyses}

Data were analyzed using the SAS-JMP statistical package. Data for PGs and HETE production as measured by EIA are presented as "Fold-basal” to represent the response of the cells to treatment compared with basal production. Because hOB cells are derived from the heterogeneous human population, variation between cell strains makes a normalization method (i.e.,"Fold basal”) desirable to assist in permitting meaningful comparisons. Data are presented as the mean $\pm \mathrm{SEM}$ of $\mathrm{N}$ experiments using different hOB cell strains. Intra-assay coefficient of variation (CV) was calculated by comparing variation between replicate samples using the formula CV=(Std. Dev./Mean)*100. Inter-assay coefficient of variation (CV) was calculated by comparing variation between samples obtained from similar experiments performed on different days using the similar kit using the formula $\mathrm{CV}=($ Std. Dev./Mean)*100. In the RT-PCR studies, individual band intensities were first normalized to the samples respective GAPdH band intensity. These values were then expressed as a percentage of control sample value, and treatment effects were analyzed.

The data were analyzed by the paired t-test (e.g. cytokine effects on PGE 2 production by hOB cells) using the SAS-JMP statistical package. Statistical significance was examined by these tests using $\mathrm{p}<0.05$ as the significance level. 


\section{RESULTS}

Effects of cytokines on biosynthesis of arachidonic acid metabolites

Previously published TLC analyses (Fig. 4; with permission from Dr. Philip

E. Keeting) and EIA studies from this laboratory guided investigations into EIAs to

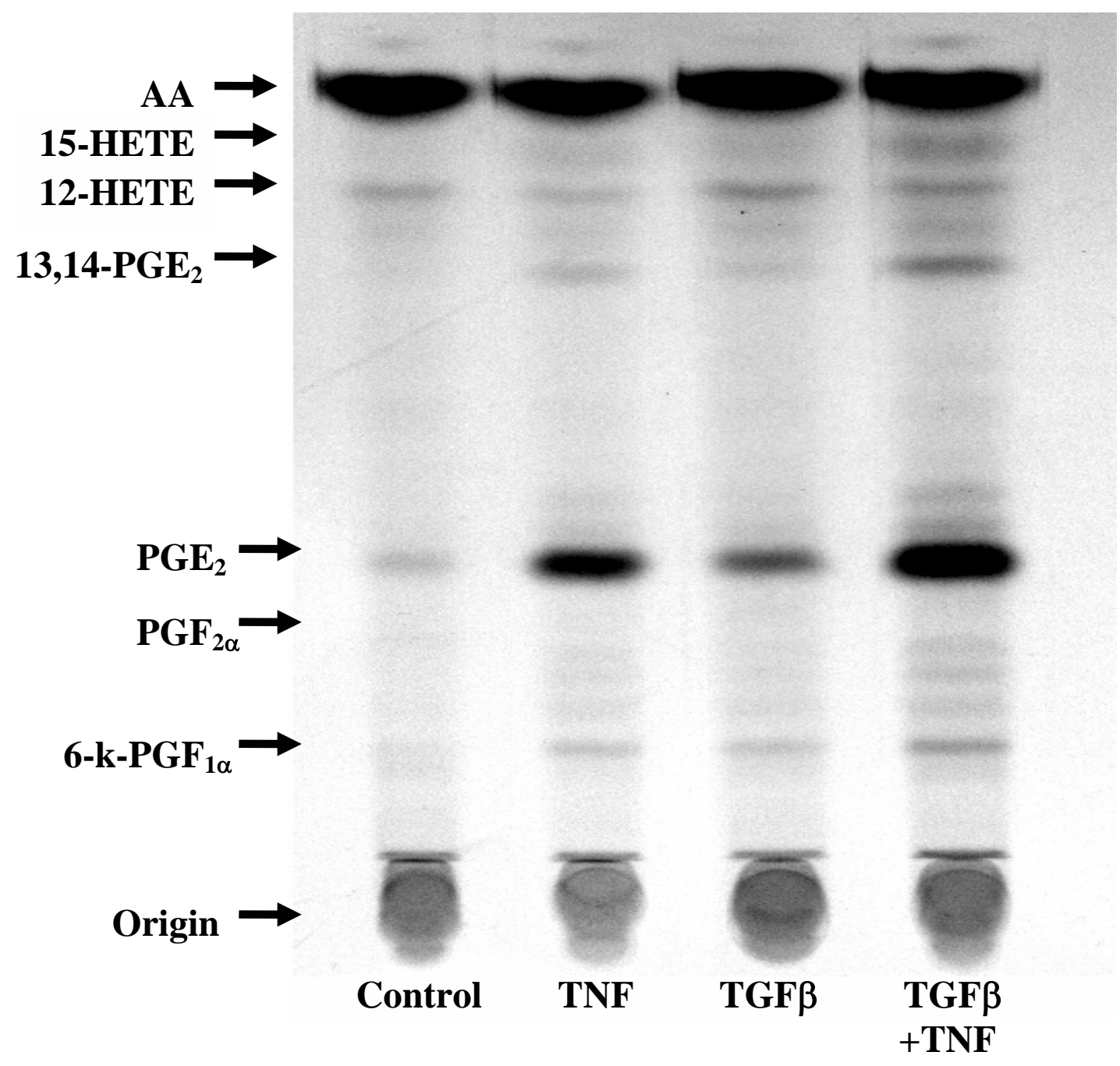

Figure 4. hOB cells were preradiolabeled with 1- $\left[{ }^{14}\right.$ C]arachidonic acid for 24 hours, and stimulated with or without cytokines, as indicated. Twenty-four-hour cell-conditioned media were collected, extracted, products separated by thin layer chromatography, and the TLC plates used to expose x-ray film. Metabolites were identified by the comigration of authentic standards. 
further define and characterize the role of cytokines in the modulation of PG and HETE production in hOB cell cultures. These TLC studies indicated that the application of TGF $\beta$ or TNF $\alpha$ alone, and in combination, elevated 1- $\left[{ }^{14} \mathrm{C}\right]-\mathrm{PGE}_{2}$ formation several fold, and produced modest increases of perhaps two-five fold in the levels of 1-[ $\left[{ }^{14} \mathrm{C}\right]-6-$-keto-PGF $1 \alpha$ in hOB cells. In some of these studies a band corresponding to $\mathrm{PGF}_{2 \alpha}$ was observed. Bands corresponding to the migration of authentic 12-HETE and 15-HETE were also seen in some experiments. The 15HETE band was increased in cytokine stimulated specimens, and appeared to be decreased when aspirin or ibuprofen, both inhibitors of COX, was included. 12HETE formation did not appear to vary by treatment. Production of other PG metabolites, such as $\mathrm{TxB}_{2}$ or 5-HETE, by the hOB cells was not detected using the TLC procedure.

In the present studies, conditioned media harvested from hOB cell cultures were assayed by prostalandin specific EIAs to determine quantitatively the effects of cytokines on $\mathrm{PGE}_{2}$, 6-keto-PGF $1 \alpha, \mathrm{PGF}_{2 \alpha}, \mathrm{PGD}_{2}$, thromboxane $\left(\mathrm{TXB}_{2}\right)$ and on 15HETE biosynthesis. The main product of $\mathrm{PGH}_{2}$ in the conditioned media was found to be $\mathrm{PGE}_{2}$, with lesser amounts of 6-keto-PGF ${ }_{1 \alpha}, \mathrm{PGF}_{2 \alpha}$, and $\mathrm{PGD}_{2}$ detected (Figure 5 and Table 2). $\mathrm{TXB}_{2}$ was not detected in control samples, or in samples stimulated with cytokines. 15-HETE was produced by the hOB cells, and was sensitive to modulation by the cytokines and ibuprofen.

EIA analysis indicated that $\mathrm{PGE}_{2}$ was the predominant PG metabolite released by unstimulated hOB cells and its synthesis was increased more than other PGs in cells treated with TGF $\beta$ and TNF $\alpha$, both separately and in combination, 
Increases in PGs and 15-HETE when hOB cells treated by cytokines

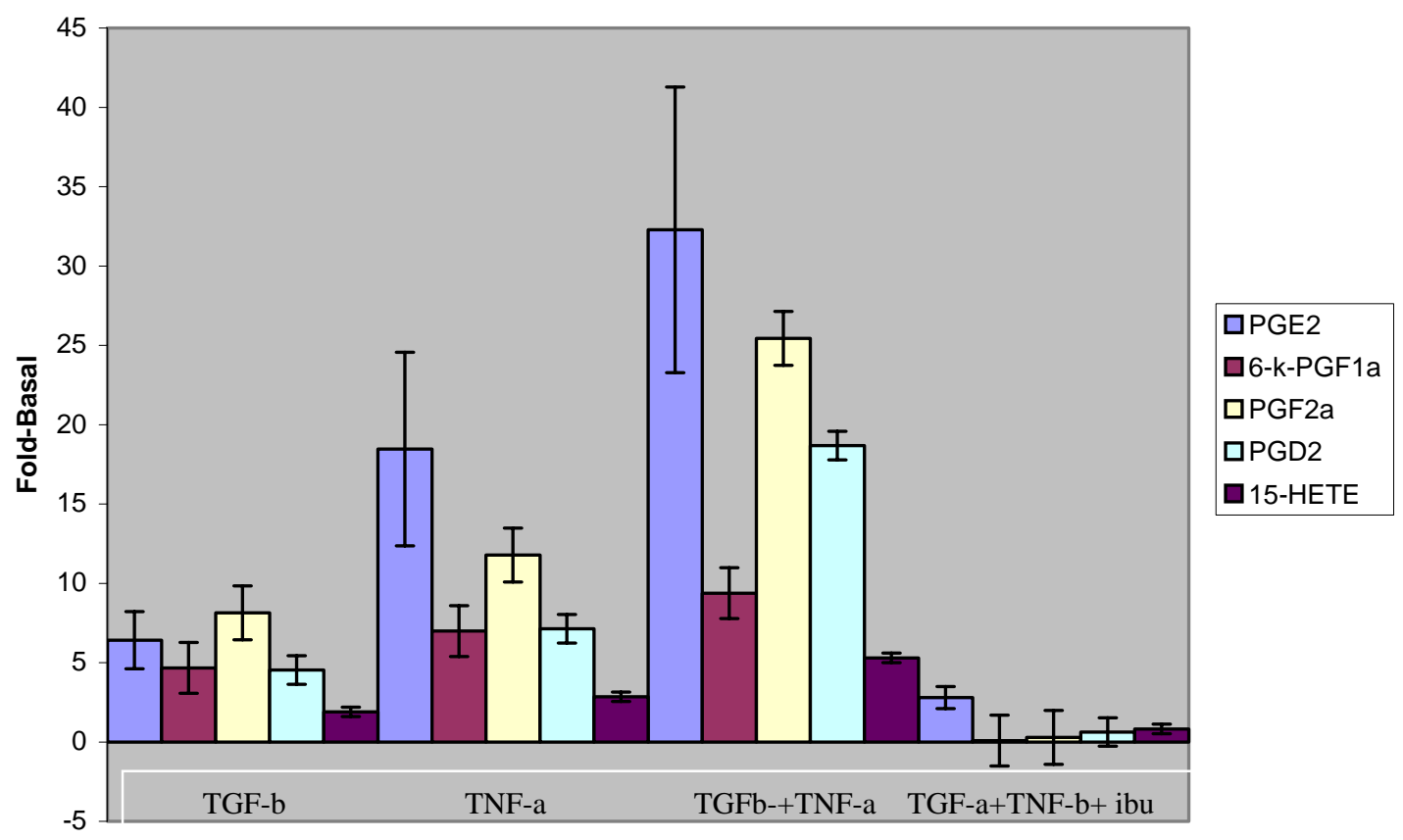

Fig. 5. Summary of PGs and 15-HETE stimulation by TGF- $\beta$ and TNF- $\alpha$

hOB cells were treated with 20 nM TNF- $\alpha$ and 40 pM TGF- $\beta$ in combination or separately. In some specimens, fifty $\mu M$ of ibuprofen was used in combination with 20 nM TNF- $\alpha$ and 40 pM TGF- $\beta$ for 24 hrs in 10\% FBS supplemented medium. PGs and HETEs were assayed by EIA $(N=5)$. 
agreeing with previous observations (Xu et al., 1997) (Table. 2). Basal production of $\mathrm{PGE}_{2}$ in control samples was measured at $9.5 \pm 5.1 \mathrm{ng} / \mathrm{ml}(\mathrm{N}=5)$. TNF $\alpha$ alone and in combination with TGF $\beta$ over a $24 \mathrm{hr}$ incubation significantly increased $\mathrm{PGE}_{2}$ levels $(\mathrm{N}=5, \mathrm{p}<0.05)$. In combination the cytokines increased $\mathrm{PGE}_{2}$ formation to $32.3 \pm 9$ fold-basal $(\mathrm{N}=5, \mathrm{p}<0.05)$, a response dramatically different from the increase elicited by TGF $\beta$ alone ( $6.4 \pm 1.8$ fold; $\mathrm{p}<0.05$ vs. control), but not significantly different from the response to TNF $\alpha(18.5 \pm 6.1$ fold; $\mathrm{p}<0.05$ vs. control). Samples treated with TGF $\beta$ and TNF $\alpha$ in the presence of ibuprofen ( $2.8 \pm 0.7$ fold; $\mathrm{p}<0.05$ vs. control; $\mathrm{p}<0.05$ vs. TGF $\beta$, TNF $\alpha$ or Both) exhibited an attenuated response. A significant difference in $\mathrm{PGE}_{2}$ formation was found between TNF $\alpha$ treated samples (18.5 \pm 6.1 fold-basal) vs. TGF $\beta$ plus TNF $\alpha$ plus ibuprofen ( $2.8 \pm 0.7$ fold basal) (Table 2).

6-keto-PGF $F_{1 \alpha}$ was the second most predominant PG found in hOB cells, although the amounts found did not approach the amount of $\mathrm{PGE}_{2}$ under either basal $(0.5 \pm 0.1 \mathrm{ng} / \mathrm{ml}$ vs. $9.5 \mathrm{ng} / \mathrm{ml})$ or maximal stimulated conditions $(4.7 \pm 0.2 \mathrm{ng} / \mathrm{ml}$ vs. $306.9 \pm 45 \mathrm{ng} / \mathrm{ml})$. The cytokine dependent increase in 6-keto-PGF ${ }_{1 \alpha}$ formation in hOB cells was a significant $9.4 \pm 1.6$ fold-basal in specimens treated with TGF $\beta$ and TNF $\alpha$ in combination (Table 3). Ibuprofen inclusion blocked the cytokine stimulated increase ( $0.1 \pm 0.0$ fold-basal). TNF $\alpha$ increased 6-keto-PGF ${ }_{1 \alpha}$ formation significantly to $7.0 \pm 2.0$ fold-basal.

Basal production of $\mathrm{PGF}_{2 \alpha}$ in control samples was $0.2 \pm 0.0 \mathrm{ng} / \mathrm{ml}(\mathrm{N}=5)$

(Table 4). PGF $_{2 \alpha}$ production was stimulated by cytokines individually, and in 
Table 2. Effect of cytokines and Ibuprofen on $\mathrm{PGE}_{2}$ synthesis by hOB cells

\begin{tabular}{|l|c|}
\hline Treatment & Fold Basal \\
\hline Control & $1.0 \pm 0.0$ \\
\hline TGF- $\beta$ & $6.4 \pm 1.8$ \\
\hline TNF- $\alpha$ & $18.5 \pm 6.1^{\mathrm{a}}$ \\
\hline TNF- $\alpha+$ TGF- $\beta$ & $32.3 \pm 9.0^{\mathrm{a}}$ \\
\hline TNF- $\alpha+$ TGF- $\beta+$ ibuprofen & $2.8 \pm 0.7^{\mathrm{b}, \mathrm{c}}$ \\
\hline
\end{tabular}

hOB cells were treated with $20 \mathrm{nM}$ TNF- $\alpha$ and $40 \mathrm{pM}$ TGF- $\beta$ in combination or separately. Fifty $\mu \mathrm{M}$ of ibuprofen was used in combination with $20 \mathrm{nM}$ TNF- $\alpha$ and 40 pM TGF- $\beta$ for 24 hrs in $10 \%$ FBS supplemented medium. $P G E_{2}$ was assayed by EIA $(N=5)$. The data are presented as the mean \pm SEM of five individual cell strains. The basal production of $P G E_{2}$ was $9.5 \pm 5.1 \mathrm{ng} / \mathrm{ml}$.

${ }^{a}, p<0.05$, by comparison with control (by student's $t$-test).

${ }^{b}, p<0.05$, by comparison with TNF- $\alpha$ (by student's t-test).

', $p<0.05$, by comparison with TNF- $\alpha+$ TGF- $\beta$ (by student's t-test). 
Table 3. Effect of cytokines and Ibuprofen on 6-keto-PGF ${ }_{1 \alpha}$ synthesis by hOB cells

\begin{tabular}{|l|c|}
\hline Treatment & Fold Basal \\
\hline Control & $1.0 \pm 0.0$ \\
\hline TGF- $\beta$ & $4.7 \pm 1.6$ \\
\hline TNF- $\alpha$ & $7.0 \pm 2.0^{\mathrm{a}}$ \\
\hline TNF- $\alpha+$ TGF- $\beta$ & $9.4 \pm 1.6^{\mathrm{a}}$ \\
\hline TNF- $\alpha+$ TGF- $\beta+$ ibuprofen & $0.1 \pm 0.0^{\mathrm{b}, \mathrm{c}}$ \\
\hline
\end{tabular}

hOB cells were treated with 20 nM TNF- $\alpha$ and 40 pM TGF- $\beta$ in combination or separately. Fifty $\mu M$ of ibuprofen was used in combination with $20 \mathrm{nM}$ TNF- $\alpha$ and 40 pM TGF- $\beta$ for 24 hrs in 10\% FBS supplemented medium. 6-keto-PGF $F_{1 \alpha}$ was assayed by $E I A(N=5)$. The data are presented as the mean \pm SEM of five individual cell strains. The basal production of 6-keto-PGF ${ }_{1 \alpha}$ was $0.5 \pm 0.1 \mathrm{ng} / \mathrm{ml}$.

${ }^{a}, p<0.05$, by comparison with control (by Tukey-Kramer's method).

b, $p<0.05$, by comparison with TNF- $\alpha$ (by Tukey-Kramer's method).

${ }^{c}, p<0.05$, by comparison with TNF- $\alpha+T G F-\beta$ (by Tukey-Kramer's method). 
Table 4. Effect of cytokines and Ibuprofen on $\mathrm{PGF}_{2 \alpha}$ synthesis by hOB cells

\begin{tabular}{|l|l|}
\hline Treatment & Fold Basal \\
\hline Control & $1.0 \pm 0.0$ \\
\hline TGF- $\beta$ & $8.1 \pm 1.7^{\mathrm{b}}$ \\
\hline TNF- $\alpha$ & $11.8 \pm 4.5^{\mathrm{a}, \mathrm{b}}$ \\
\hline TNF- $\alpha+$ TGF- $\beta$ & $25.4 \pm 4.0^{\mathrm{a}}$ \\
\hline TNF- $\alpha+$ TGF- $\beta+$ ibuprofen & $0.3 \pm 0.1^{\mathrm{b}}$ \\
\hline
\end{tabular}

hOB cells were treated with 20 nM TNF- $\alpha$ and 40 pM TGF- $\beta$ in combination or separately. Fifty $\mu M$ of ibuprofen was used in combination with $20 \mathrm{nM}$ TNF- $\alpha$ and 40 pM TGF- $\beta$ for 24 hrs in 10\% FBS supplemented medium. PGF $2 \alpha$ was assayed by EIA $(N=5)$. The data are presented as the mean \pm SEM of five individual cell strains. The basal production of $P_{G F}$ was $0.2 \pm 0.0 \mathrm{ng} / \mathrm{ml}$.

${ }^{a}, p<0.05$, by comparision with control (by Dunnett's method)

${ }^{b}, p<0.05$, by comparision with TNF- $\alpha$ and TGF- $\beta$ in combination (by student's $t$ test). 
combination, reaching a maximum increase to $25.4 \pm 4.0$ fold-basal $(\mathrm{N}=5)$ with the combination treatment of TGF $\beta$ plus TNF $\alpha$. TNF $\alpha$ individually elevated $\mathrm{PGF}_{2 \alpha}$ production significantly to $11.8 \pm 4.5$ fold-basal.

There was also a significant difference in the stimulated $\mathrm{PGF}_{2 \alpha}$ synthesis between the combined application of TGF $\beta$ and TNF $\alpha$ (25.4 \pm 4.0 fold-basal) versus treatment of TGF $\beta$ alone $(8.1 \pm 1.7$ fold-basal $)$ or TNF $\alpha$ alone $(11.8 \pm 4.5$ foldbasal). Ibuprofen treatment blocked the cytokine stimulated increase in PGF $2 \alpha$ production $(0.3 \pm 0.1$ fold-basal $)$.

$\mathrm{PGD}_{2}$ production by hOB cells had not been reported previously. In the present studies, the level of $\mathrm{PGD}_{2}$ in unstimulated samples was measured at $0.02 \pm$ $0.01 \mathrm{ng} / \mathrm{ml}(\mathrm{N}=5)$. The capacity of the cytokines in combination and individually to modulate $\mathrm{PGD}_{2}$ formation was examined, and TGF $\beta$ and TNF $\alpha$ in combination stimulated $\mathrm{PGD}_{2}$ formation significantly $(18.7 \pm 2.9$ fold-basal; $\mathrm{p}<0.05)$. This increase in $\mathrm{PGD}_{2}$ formation with TGF $\beta$ plus $\mathrm{TNF} \alpha$ in combination was significantly different from samples treated with TGF $\beta$ alone (4.5 \pm 0.9 fold-basal), TNF $\alpha$ alone (7.1 \pm 1.9 fold-basal), and TGF $\beta$ and TNF $\alpha$ plus ibuprofen (0.6 \pm 0.1 fold-basal). TNF $\alpha$ alone elevated $\mathrm{PGD}_{2}$ formation significantly over basal $\mathrm{PGD}_{2}$ formation (7.1 \pm 1.9 fold-basal) (Table 5).

The basal level of 15-HETE in hOB cell samples was $0.5 \pm 0.1 \mathrm{ng} / \mathrm{ml}(\mathrm{N}=5)$ (Table 6). TGF $\beta$ and TNF $\alpha$ applied in combination elevated 15-HETE biosynthesis significantly (5.3 \pm 0.8 fold-basal). There was a significant difference in the 15 HETE levels between application of TGF $\beta$ and TNF $\alpha$ in combination compared to 
Table 5. Effect of cytokines and Ibuprofen on $\mathrm{PGD}_{2}$ synthesis by hOB cells

\begin{tabular}{|l|c|}
\hline Treatment & Fold Basal \\
\hline Control & $1.0 \pm 0.0$ \\
\hline TGF- $\beta$ & $4.5 \pm 0.9^{\mathrm{c}}$ \\
\hline TNF- $\alpha$ & $7.1 \pm 1.9^{\mathrm{a}, \mathrm{c}}$ \\
\hline TNF- $\alpha+$ TGF- $\beta$ & $18.7 \pm 2.9^{\mathrm{a}}$ \\
\hline TNF- $\alpha+$ TGF- $\beta+$ ibuprofen & $0.6 \pm 0.1^{\mathrm{b}, \mathrm{c}}$ \\
\hline
\end{tabular}

hOB cells were treated with $20 \mathrm{nM}$ TNF- $\alpha$ and $40 \mathrm{pM}$ TGF- $\beta$ in combination or separately. Fifty $\mu M$ of ibuprofen was used in combination with $20 \mathrm{nM}$ TNF- $\alpha$ and 40 pM TGF- $\beta$ for 24 hrs in $10 \%$ FBS supplemented medium. $P G D_{2}$ was assayed by EIA $(N=4)$. The data are presented as the mean \pm SEM of four individual cell strains. The basal level of $P G D_{2}$ was $0.02 \pm 0.05 \mathrm{ng} / \mathrm{ml}$.

${ }^{a}, p<0.05$, by comparision with control (by student's $t$-test).

${ }^{b}, p<0.05$, by comparision with TNF- $\alpha$ (by student's t-test).

c, $p<0.05$, by comparision with TNF- $\alpha+T G F-\beta$ (by student's t-test). 
Table 6. Effect of cytokines and Ibuprofen on 15-HETE synthesis by hOB cells

\begin{tabular}{|l|c|}
\hline Treatment & Fold Basal \\
\hline Control & $1.0 \pm 0.0$ \\
\hline TGF- $\beta$ & $1.9 \pm 0.3^{\mathrm{c}}$ \\
\hline TNF- $\alpha$ & $2.9 \pm 0.9^{\mathrm{a}, \mathrm{c}}$ \\
\hline TNF- $\alpha+$ TGF- $\beta$ & $5.3 \pm 0.8^{\mathrm{a}}$ \\
\hline TNF- $\alpha+$ TGF- $\beta+$ ibuprofen & $0.8 \pm 0.1^{\mathrm{b}, \mathrm{c}}$ \\
\hline
\end{tabular}

hOB cells were treated with $20 \mathrm{nM}$ TNF- $\alpha$ and 40 pM TGF- $\beta$ in combination or separately. Fifty $\mu M$ of ibuprofen was used in combination with $20 \mathrm{nM}$ TNF- $\alpha$ and 40 pM TGF- $\beta$ for $24 \mathrm{hrs}$ in 10\% FBS supplemented medium. 15-HETE was assayed by EIA $(N=5)$. The data are presented as the mean \pm SEM of five individual cell strains. The basal level of 15-HETE was $0.5 \pm 0.1 \mathrm{ng} / \mathrm{ml}$.

${ }^{a}, p<0.05$, by comparision with control (by student's t-test).

${ }^{b}, p<0.05$, by comparision with TNF- $\alpha$ (by student's $t$-test).

', $p<0.05$, by comparision with TNF- $\alpha$ and TGF- $\beta$ (by student's t-test). 
treatment with TGF $\beta$ alone (1.9 \pm 0.3 fold-basal) or with TNF $\alpha$ alone (2.9 \pm 0.9 fold basal). Ibuprofen application inhibited the cytokine stimulated increase in 15-HETE (0.8 \pm 0.1 fold-basal) (Table 6).

EIAs were also performed to measure $\mathrm{TXB}_{2}$ in unstimulated hOB cells, and cells treated with cytokines separately and in combination. $\mathrm{TXB}_{2}$ was undetectable. 


\section{Effect of cytokines on Prostaglandin $\mathrm{E}_{2}$ synthases}

The possibility that the up-regulation of $\mathrm{PGE}_{2}$ synthesis elicited by cytokines might have resulted from an increased level of the terminal PGE 2 synthases (cPGES and mPGES) which act downstream of COX enzymes in the arachidonic acid metabolic cascade for $\mathrm{PGE}_{2}$ production was tested. Transcripts for cPGES and mPGES was assessed by the reverse-transcriptase polymerase chain reaction using specific primers for human cPGES and mPGES (Stichtenoth et al., 2001). cPGES and mPGES cDNAs had 482 and 458 nucleotides respectively.

cPGES mRNA in hOB cells was detected in unstimulated control samples (Fig. 5.). Upon dual cytokine stimulation, an up-regulation of cPGES mRNA was observed. A non-significant change in the cPGES mRNA level was observed in specimens stimulated singly with TGF $\beta(2.5 \pm 0.4$ fold basal, $N=4)$, or with TNF $\alpha$ (4.6 \pm 1.4 fold basal, $N=4)$. The conjoint treatment of TGF $\beta$ and TNF $\alpha$ significantly increased the steady state level of cPGES mRNA (5.3 \pm 1.3 fold-basal, $N=4$, $\mathrm{p}<0.05)$

The mRNA levels of mPGES, was assessed utilizing RT-PCR technique, and the outcome for mPGES mRNA assays was generally similar to that of cPGES in response to the proinflammatory cytokines. mPGES mRNA expression was assayed in hOB cells following treatment with TGF $\beta$ ( $2.7 \pm 0.7$ fold-basal, $\mathrm{N}=4$ ), or with TNF $\alpha$ versus control samples ( $4.5 \pm 1.6$ fold-basal, $N=4)$. Neither response reached significance in these studies. TGF $\beta$ plus TNF $\alpha$ in combination significantly increased the mPGES mRNA level (5.3 \pm 1.7 fold basal, $N=4$, $p<0.05$ ) (Fig. 6.). 

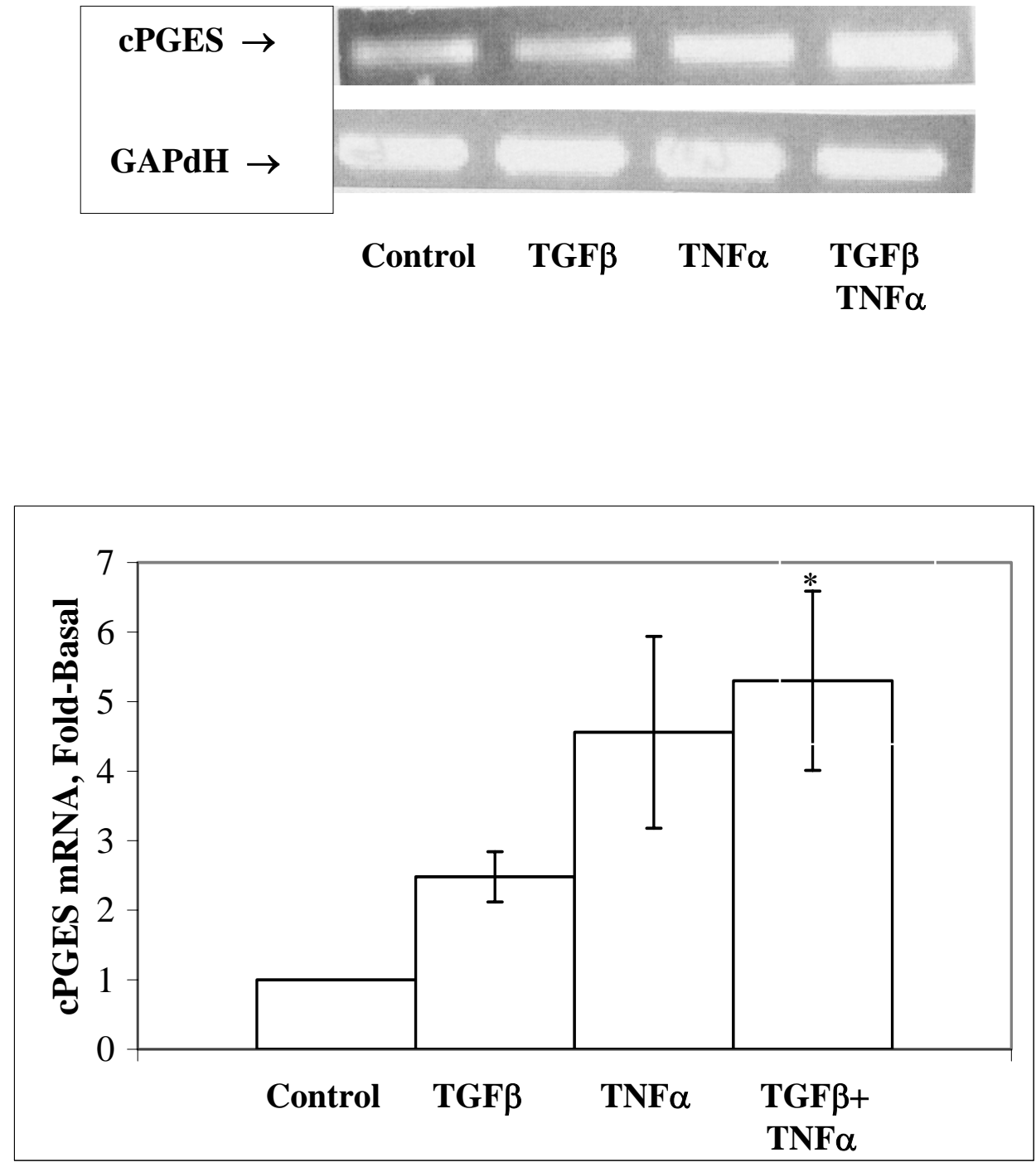

Figure 6. RT-PCR based experiments tested whether the mRNA level of CPGES was sensitive to TGF $\beta$ and/or TNF $\alpha$ treatment. The top panel illustrates the results of an experiment using hOB cells from a 23 year old woman. Specimens were treated with or without TGF $\beta$, TNF $\alpha$, or TGF $\beta$ plus TNF $\alpha$ for 6-8 hours. The bar graphs represent the relative levels of CPGES mRNA after normalizing to GAPdH levels in the pooled samples $(N=4)$.

*, $p<0.05$, by comparision with control samples (Student's t-test). 

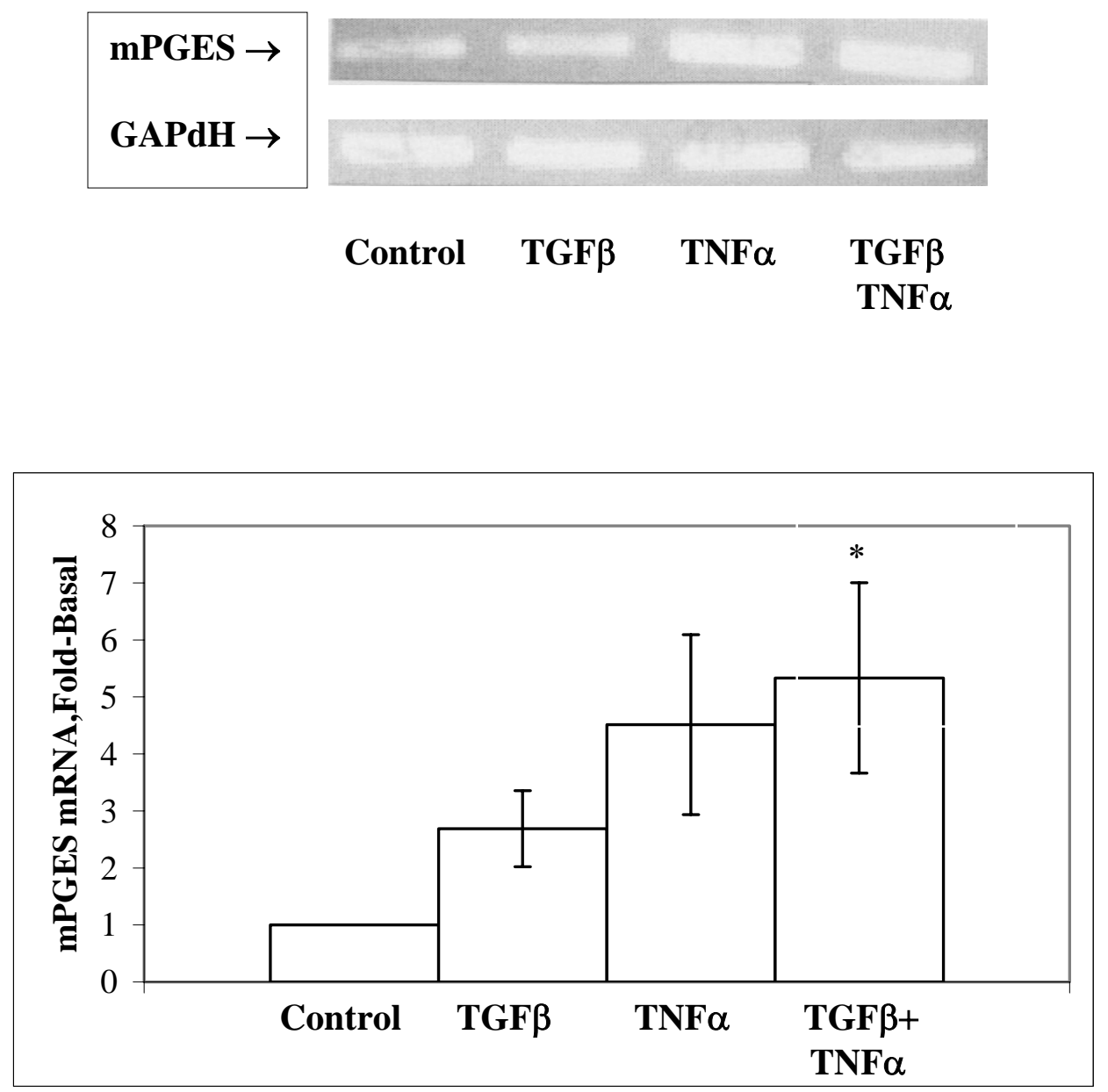

Figure 7. RT-PCR based experiments tested whether the mRNA level of mPGES was sensitive to TGF $\beta$ and/or TNF $\alpha$ treatment. The top panel illustrates the results of an experiment using hOB cells from a 75 year old man. Specimens were treated with or without TGF $\beta$, TNF $\alpha$, or TGF $\beta$ and TNF $\alpha$ for 6-8 hours. The bar graphs represents the relative levels of mPGES mRNA after correcting for GAPdH levels in the various samples $(N=4)$.

*, $p<0.05$, by comparision with control samples (Student’s t-test). 


\section{Effect of cytokines on 15-lipoxygenase type-II}

The steady-state level of 15-Lipoxygenase type-II mRNA in the hOB cells was determined in control samples and specimens treated with TGF $\beta$ and/or TNF $\alpha$, IL-3 and IL-1 $\beta$ (Fig. 7a,b). A significant increase in 15-LOX type-II mRNA level was evident in specimens treated with TNF $\alpha$ alone $(47.9 \pm 22$ fold-basal). The specimens treated with following treatments elicited a non-significant increase in 15LOX type-II mRNA level, with TGF $\beta$ alone (2.7 \pm 1.1 fold-basal); TGF $\beta$ plus TNF $\alpha$ (11.6 \pm 4.6 fold-basal); IL-3 (5.7 \pm 2.9 basal) and with IL-1 $\beta$ (14.2 \pm 9.3 fold-basal).

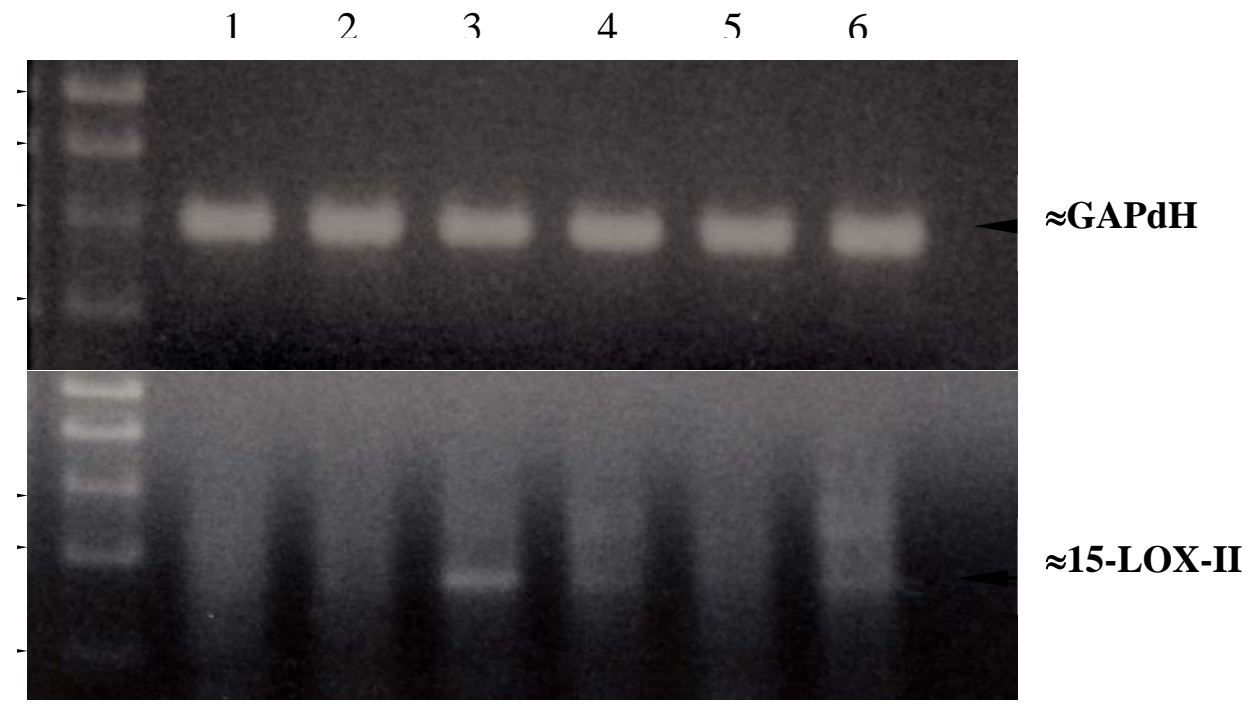

1=Control; $2=\mathrm{TGF} \beta ; 3=\mathrm{TNF} \alpha$; 4=TGF $/ \mathrm{TNF} \alpha ; 5=\mathrm{IL}-3 ; 6=\mathrm{IL}-1 \beta$

Figure 8a. RT-PCR based experiments tested whether the mRNA level of 15lipoxygenase type-II was sensitive to TGF $\beta$ and/or TNF $\alpha, I L-3$ and IL-1 $\beta$ treatments. Specimens were treated with or without TGF $\beta$, TNF $\alpha$, or TGF $\beta$ plus TNF $\alpha$, IL-3, or IL-1 $\beta$ for 6-8 hours. The top panel illustrates the results of an experiment using hOB cells from a 75 year old man. 


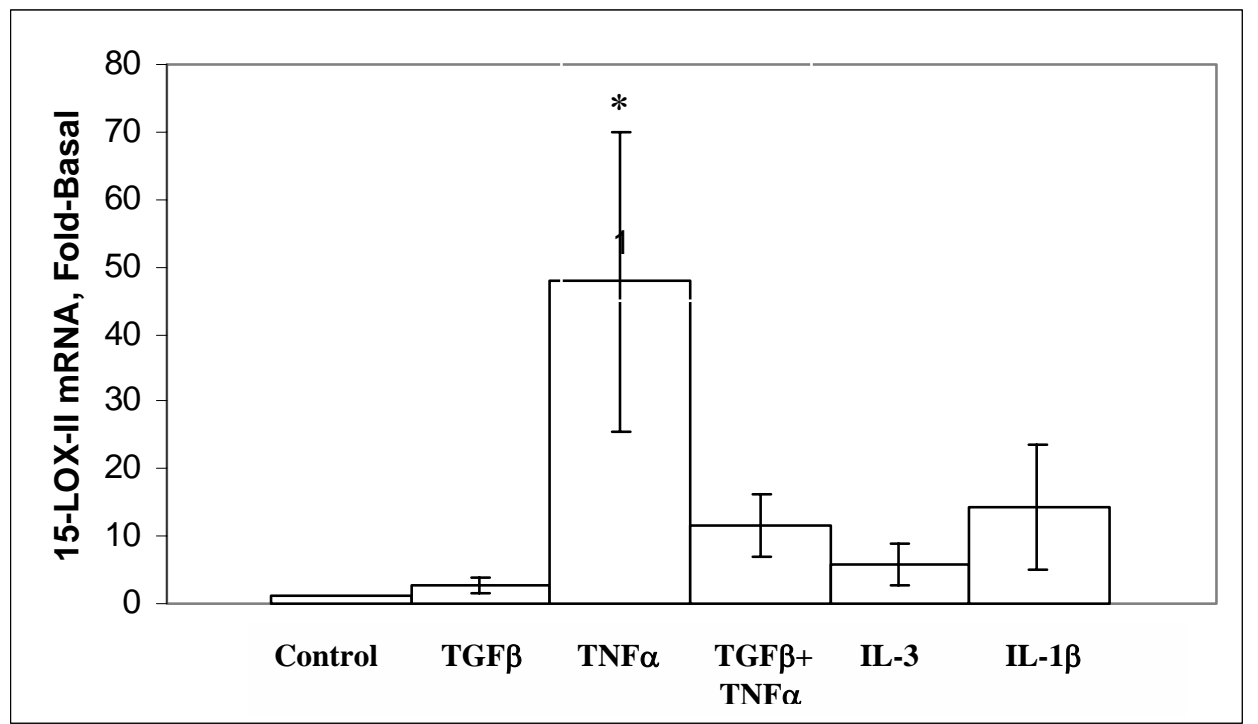

Figure 8b. RT-PCR based experiments tested whether the mRNA level of 15lipoxygenase type-2 was sensitive to TGF $\beta$ and/or TNF $\alpha, I L-3$ and IL-1 $\beta$ treatments. *, significantly different from control and other treatments at $p<0.05, N=3$ (by student's t-test). 


\section{DISCUSSION}

Our enzyme-immunoassay data show that the predominant prostaglandin metabolite found in the conditioned media of unstimulated and cytokine-challenged hOB cells was $\mathrm{PGE}_{2}$. Basal $\mathrm{PGE}_{2}$ production may have been primarily the result of a constitutive COX-1 activity (Smith et al., 1996). The treatment with TGF $\beta$ or TNF $\alpha$, alone and in combination, increased $\mathrm{PGE}_{2}$ biosynthesis; the maximum response was a 32-fold increase following stimulation by the conjoint application of TGF $\beta$ plus TNF $\alpha$, probably due to increased COX-2 expression and activity (Smith et al., 1996; Xu et al., 1997). Researchers have demonstrated the involvement of COX-2 induction and subsequent increased $\mathrm{PGE}_{2}$ production by cytokines, such as IL-1 $\beta$ and TNF $\alpha$, in the bone resorptive disorders of postmenopausal osteoporosis and rheumatoid arthritis joint destruction (Kawaguchi et al., 1995).

TGF $\beta$ and TNF $\alpha$ are products of various types of cells including hOB cells, and hOB cells are responsive to treatment with these cytokines when added exogenously (Raisz, 1993; Kuroki et al., 1994). Thus, TGF $\beta$ and TNF $\alpha$ serve as autocrine/paracrine regulators in osteoblast cells. Supporting this statement is the observation by Dodds et al. (1994) of TGF $\beta$ and TNF $\alpha$ mRNA expression in osteoblasts localized to remodeling sites in human bone sections. Cytokines regulate

prostaglandin production in a tissue specific manner, and TGF $\beta$ has been reported to promote, and to oppose, augmented PG production with specificity to different tissues (Goppelt-Struebe, 1995). TNF $\alpha$ appears to act solely to increase PG biosynthesis (Crofford, 1997). 
The results of the present studies are consistent with the results and conclusions drawn from an earlier published report from this laboratory (Xu et al., 1997). An overall 32-fold potentiation of $\mathrm{PGE}_{2}$ biosynthesis by TGF $\beta$ and TNF $\alpha$ treatment was recorded in the present studies; a 22-fold increase under these conditions was previously reported, and described as synergistic (Xu et al., 1997). Opposing/or synergistic interactions of TGF $\beta$ and TNF $\alpha$ are not restricted to hOB cells but are also seen in studies of rat mesangial cells, human airway epithelial cells, and fetal rat calvarial osteoblasts. In rat mesangial cells, TGF $\beta$ and TNF $\alpha$ in combination synergistically up-regulate fibronectin expression (Pawluczyk et al., 1998). Disparate interaction effects for TGF $\beta$ and TNF $\alpha$ mediation of GM-CSF and IL-8 expression in human airway epithelial cells have been reported (Jagels et al., 2000). In fetal rat calvarial osteoblasts a TNF $\alpha$-stimulated increase in secretory $\mathrm{PLA}_{2}$ release was opposed by TGF $\beta$, as was a TNF $\alpha$ - dependent increase in COX-2 mRNA expression (Pruzanski et al., 1998).

In our studies the inhibitory effect of ibuprofen on $\mathrm{PGE}_{2}$ production in hOB cells was obvious. The non-steroidal antinflammatory drugs (NSAIDs, e.g., ibuprofen) inhibit prostaglandin biosynthesis by inhibiting the cyclooxygenase enzymes. The present results were consistent with the earlier published report by Xu et al. (1997).

It should be noted that the present study is limited to in vitro experiments. In fact, $\mathrm{PGE}_{2}$, particularly in the bone cells, has a very important role since it is known to have potent effects not only on bone resorption (Kawaguchi et al., 1995; Raisz 1999; Miyaura et al., 2000; Sakuma et al., 2000), but also on bone 
formation in vivo (Jee et al., 1985; Jee et al., 1987; Mori et al., 1990; Miller et al., 1994). The recognized resorption effect of prostaglandins on bone has been repeatedly confirmed since it was first reported by Klein and Raisz (1970). Numerous reports indicate that $\mathrm{PGE}_{2}$ stimulates bone resorption in mouse and rat bone cultures (Farndale et al., 1988), participates in the development of the bone resorbing osteoclasts from mononuclear cells, and can directly regulate osteoclast activity (Raisz et al., 1975; Roodman, 1996). The osteogenic effects are mainly seen when a substantial amount of exogenous $\mathrm{PGE}_{2}$ was applied locally or systemically (Raisz et al., 1993; Kawaguchi et al., 1995), and $\mathrm{PGE}_{2}$ can prevent ovariectomyinduced cancellous bone-loss in rats (Jee et al., 1990; Mori et al., 1992; Welch et al., 1993). Thus, the regulatory actions of $\mathrm{PGE}_{2}$ in bone are diverse, and include the mediation of cyclic nucleotide accumulation (Partridge et al., 1981; Klein-Nulend et al., 1990; Yu et al., 1976; Atkins et al., 1977), cell proliferation (Hakeda et al., 1987; Raisz et al., 1990) are among its other recognized actions (Raisz et al., 1983; Raisz, 1988; Shen et al., 1986; Evans et al., 1990).

Prostaglandin production is a multi-step process (Smith et al., 1996). Esterified arachidonic acid is released from membrane glycerophospholipids by activated phospholipases. The activity of the downstream cyclooxygenase enzyme is rate-limited by liberated arachidonic acid availability (Smith et al., 1996), which is supplied through phospholipase $A_{2}$ hydrolysis of membrane glycerophospholipids. This available free arachidonic acid can then be used as a substrate by the COX enzymes to form the unstable transitional cyclic endoperoxide $\mathrm{PGH}_{2}$. Further, 
downstream of the cyclooxygenases, terminal conversion of $\mathrm{PGH}_{2}$ to $\mathrm{PGE}_{2}$ takes place, which may be catalyzed by either of two isoforms of $\mathrm{PGE}_{2}$ synthase (PGES).

The regulatory mechanisms of $\mathrm{PGE}_{2}$ production may involve multiple regulation mechanisms. One mechanism regulating cytokine-stimulated $\mathrm{PGE}_{2}$ production could be effects on release of arachidonic acid from membrane glycerophospholipids by the activity of cytosolic PLA $\mathrm{P}_{2}\left(\mathrm{CPLA}_{2}\right)$. This enzyme is critical for PG biosynthesis (Fujishima et al., 1999) and provides the necessary substrate for the newly expressed COX-2 protein after cytokine stimulation. It has been reported that TNF $\alpha$ mediates PG biosynthesis by activating $\mathrm{CPLA}_{2}$ and by increasing the rate of phospholipase $\mathrm{A}_{2}$ synthesis in bone cultures (Yanaga et al., 1992; Kawaguchi et al., 1996), an effect that may be duplicated in hOB cells (Secreto et al., submitted to Prostaglandins \& Other Lipid Mediators). Proinflammatory cytokines have also been reported to stimulate PLA $\mathrm{A}_{2}$ activity and/or expression in mesangial and epithelial cells (Pfeilschifter et al., 1989; Newton et al., 1997).

The second $\mathrm{PGE}_{2}$ production regulatory site is the inducible cyclooxygenase2 gene. Previous work reported from this laboratory (Xu et al., 1997) demonstrated that TGF $\beta$ and TNF $\alpha$ can independently elevate the levels of COX-2 mRNA resulting in increased formation of $\mathrm{PGE}_{2}$. When both cytokines were added to specimens concurrently, the independent stimulation of hOB cell COX-2 mRNA levels, protein levels, and prostaglandin biosynthesis was further elevated (Xu et al., 1997; Secreto et al., 2003). Some researchers have reported that TGF $\beta$ can stimulate COX-2 mRNA expression in MC3T3-E1 cells (Pilbeam et al., 1997). Our result 
shows that COX-2 activity is regulated by TGF $\beta$ and TNF $\alpha$ in hOB cells, as is evident by the stimulation of $\mathrm{PGE}_{2}$ production by these cytokine treatments. This conclusion is supported by the inhibitory effects of the NSAID ibuprofen on PGE 2 formation.

The identification of an inducible PGE synthase in hOB cells opens up new avenues for studying the regulation of $\mathrm{PGE}_{2}$ biosynthesis by pro-inflammatory cytokines. The third regulatory site for $\mathrm{PGE}_{2}$ production is the membrane-associated PGES (mPGES), which was originally designated microsomal glutathione Stransferase 1-like 1 (MGST1-L1). This is an inducible enzyme, which is coordinately induced with COX-2 and is functionally coupled with COX-2 (Jakobsson et al., 1999; Murakami et al., 2002). mPGES expression is induced by proinflammatory cytokines in various cells and tissues, now including hOB cells as indicated by the results of the present studies, and is down-regulated by dexamethasone, accompanied by changes in COX-2 expression and subsequent PGE2 production (Murakami et al., 2000).

The present study indicates the presence of the mRNAs for the microsomal and the cytosolic PGES enzymes in hOB cells. mPGES mRNA message in hOB cells appeared to increase modestly with TGF $\beta$ or TNF $\alpha$ treatment. The concurrent treatment of hOB cells with both cytokines increased mPGES mRNA levels by 5fold, to a level that was significantly different from that observed in unstimulated control hOB cells. These results are consistent with the accumulated evidence from various studies which show that mPGES is an inducible enzyme, the expression of which is markedly increased, in a manner similar to COX-2, in various cells and 
tissues following several usually proinflammatory stimuli (Jakobsson et al., 1999; Soler et al., 2000; Stichtenoth et al., 2001; Murakami et al., 2002; Yamagata et al., 2001; Han et al., 2002). Proinflammatory cytokines are reported to induce mPGES mRNA levels in synovial cells (Stichtenoth et al., 2001), thus, mPGES might also be involved in the pathophysiology of the rheumatoid arthritis joint destruction. The nearby osteoblasts may then contribute to the PGE 2 levels found in synovial fluids, perhaps, thereby exacerbating the localized inflammation. mPGES is reported to be expressed and up-regulated transcriptionally by proinflammatory cytokines in the macrophage cell line RAW 264.7 (Naraba et al., 2002). Lately, membraneassociated $\mathrm{PGE}_{2}$ synthase (mPGES) has been identified in the mouse coculture system of osteoblasts and bone marrow cells (Saegusa et al., 2003). In cultured mouse primary osteoblasts, both mPGES and cyclooxygenase-2 were induced by the bone resorptive cytokines interleukin-1, tumor necrosis factor- $\alpha$, and fibroblast growth factor-2 (Saegusa et al., 2003). Induction of mPGES was also seen in mouse long bone and bone marrow in vivo by intraperitoneal injection of lipopolysaccharide. An antisense oligonucleotide blocking mPGES expression inhibited not only $\mathrm{PGE}_{2}$ production, but also osteoclastogenesis and bone resorption stimulated by the cytokines (Saegusa et al., 2003). Unlike NSAIDs, which inhibit COX activity and suppress not only $\mathrm{PGE}_{2}$ but also production of other possibly essential prostanoids, an inhibitor of this $\mathrm{PGE}_{2}$ specific enzyme (PGES) could provide a highly selective treatment with low side effects on other aspects of tissue homeostasis. 
cPGES mRNA expression also increased in a similar fashion that of mPGES in hOB cells. These findings are in contrast with earlier reports that found cytosolic PGES (cPGES) was expressed ubiquitously and constitutively, and that mRNA levels were unaltered by proinflammatory stimuli in a wide variety of cells and tissues, where cPGES promotes COX-1 mediated immediate $\mathrm{PGE}_{2}$ production (Tanioka et al., 2000). cPGES is expressed constitutively both in the mouse coculture system of osteoblasts and bone marrow cells, and mouse long bone in vivo without being affected by bone resorptive stimuli (Saegusa et al., 2003). This COX1 and cPGES coupling is assumed to contribute to the basal production of $\mathrm{PGE}_{2}$, which plays a role in the maintenance of tissue homeostasis.

Our EIA data suggests cytokine treatments individually had little effect on 6keto-PGF ${ }_{1 \alpha}$ biosynthesis, but that the conjoint application of TGF $\beta$ and TNF $\alpha$ elevated 6-keto-PGF $1 \alpha$ by five-fold over basal production in unstimulated cells. Ibuprofen, when administered along with TGF $\beta$ and TNF $\alpha$, blocked the formation of this prostanoid. These results are in line with the earlier reported RIA and TLC data by this laboratory (Xu et al., 1997). 6-keto-PGF ${ }_{1 \alpha}$ is the second most abundant PG produced in bone (Raisz, 1995; Kawaguchi et al., 1995). PGI 2 , the precursor of 6keto-PGF ${ }_{1 \alpha}$, reportedly inhibits osteoclastic bone resorption, and completely abolishes the normally intense cytoplasmic motility of isolated osteoclasts (Chambers et al., 1983). In contrast, some investigations have shown that $\mathrm{PGI}_{2}$ is a very potent stimulator of bone resorption in fetal rat long bone organ culture (Dewhirst, 1984). Because $\mathrm{PGI}_{2}$ is formed by bone it may affect bone mineral metabolism. $\mathrm{PGI}_{2}$ is a potent vasodilator and inhibitor of platelet aggregation 
(Navamani et al., 1997). Since blood vessels produce $\mathrm{PGI}_{2}$ it is possible that $\mathrm{PGI}_{2}$ release, perhaps augmented by the resident osteoblasts, may be responsible for the frequent association between vascular invasion and resorption of bone or calcified cartilage in physiologic remodeling and pathologic osteolysis (Raisz et al., 1979).

The pattern of $\mathrm{PGF}_{2 \alpha}$ production in hOB cells on stimulation with cytokines was similar to that of $\mathrm{PGE}_{2}$; its production was elevated a significant 25 -fold by the concurrent application of TGF $\beta$ and TNF $\alpha$. This increase in $\mathrm{PGF}_{2 \alpha}$ production after cytokine stimulation suggests synergistic effects of TGF $\beta$ and TNF $\alpha$ over individual administration of these cytokines in hOB cells, whose additive effects only reached 19.9 fold-basal. The synthesis of PGF $_{2 \alpha}$ was completely blocked by ibuprofen in cells when administered along with the combination of TGF $\beta$ and TNF $\alpha$. The basal level of $\mathrm{PGF}_{2 \alpha}$ in hOB cells was somewhat similar to that of 6-keto-PGF ${ }_{1 \alpha}$, although it was only about $1 / 20^{\text {th }}$ of the basal level of the most abundant PG, PGE 2 . These results are in agreement with the previously published TLC data, which suggested that $\mathrm{PGF}_{2 \alpha}$ levels increased after stimulation with TGF $\beta$ and TNF $\alpha$ together (Xu et al., 1997).

$\mathrm{PGF}_{2 \alpha}$ is produced by bone cells, and exogenous $\mathrm{PGF}_{2 \alpha}$ can stimulate bone resorption (Raisz et al., 1990). Bone resorption was stimulated in mouse calvaria in vitro by both $\mathrm{PGE}_{2}$ and $\mathrm{PGF}_{2 \alpha}$, each in a dose-dependent manner, with $\mathrm{PGE}_{2}$ being more potent than $\mathrm{PGF}_{2 \alpha}$ (Katz et al., 1981). PGF $_{2 \alpha}$ also effected bone formation in contrast to the effects of $\mathrm{PGE}_{2}$ in cultured neonatal mouse parietal bones (Raisz et al., 1990). Studies suggest that some of the effects of $\mathrm{PGF}_{2 \alpha}$ on bone resorption, 
formation may be mediated by its capacity to stimulate an increase in endogenous PGE2 production (Raisz et al., 1990).

$\mathrm{PGD}_{2}$ was the PG metabolite found in least amount in hOB cells; its production was elevated by stimulation with TGF $\beta$ and TNF $\alpha$, either individually or in combination, in a similar pattern to that of the other prostaglandins measured. Administration of TGF $\beta$ and TNF $\alpha$ in combination elevated the $\mathrm{PGD}_{2}$ levels to about an 18-fold increase over basal and ibuprofen inclusion blocked the $\mathrm{PGD}_{2}$ formation stimulated by TGF $\beta$ and TNF $\alpha$. PGD 2 has a notable stimulatory activity on alkaline phosphatase activity and osteoblast calcification, but the effective form of $\mathrm{PGD}_{2}$ is probably a metabolite, $\Delta 12-\mathrm{PGJ}_{2}$ (Koshihara et al., 1989). $\Delta 12-\mathrm{PGJ}_{2}$ enhanced the transcription of type I procollagen (alpha 1) mRNA levels in osteoblasts (Tasaki et al., 1991). It has been reported that $\mathrm{PGJ}_{2}$ and its derivatives are effective activators of peroxisome proliferator-activated receptors alpha and gamma (PPAR- $\propto$ and PPAR- $\gamma$, respectively) (Kliewer et al., 1995). It has been recently reported that nuclear hormone receptor peroxisome proliferator activated receptor- $\gamma$, when activated, promotes adipogenesis and inhibits osteogenesis from bone marrow progenitors (Nuttall et al., 2004). A bone-selective PPAR- $\gamma$ modulator, capable of acting as an antagonist, may be required to exploit PPAR- $\gamma$ as a target for osteoporosis therapy (Akune et al., 2004; Pei et al., 2004).

Prostaglandins are important mediators that play a multiple roles in biological events, such as fever, pain, inflammation, tumorigenesis, gastrointestinal protection, vascular circulation, and bone metabolism (Raisz, 1995; Kawaguchi et al., 1995; Funk, 2001; Harris et al., 2002). Prostaglandin $\mathrm{E}_{2}, \mathrm{PGF}_{2 \alpha}$, and $\mathrm{PGI}_{2}$ are 
multifunctional regulators with both stimulatory and inhibitory effects on bone formation and resorption (Raisz, 1995; Kawaguchi et al., 1995). The research community has viewed the major effect of PGs as the stimulation of bone resorption since $\mathrm{PGE}_{2}$ was first shown to increase cyclic AMP and stimulate resorption in cultured fetal rat long bones more than 30 years ago (Klein and Raisz, 1970), but the work of Jee and others has now identified $\mathrm{PGE}_{2}$ as an anabolic agent in bone as well (Jee et al., 1985; Jee et al., 1987; Mori et al., 1990; Miller et al., 1994).

Prostaglandins exert versatile actions in diverse tissues and cells through specific cell surface receptors. Molecular biological studies revealed the primary structure of eight types of prostanoid receptor from various species. The prostanoids act on the eight types and subtypes of the receptors. They are the PGD receptor (DP), the $\mathrm{EP}_{1}, \mathrm{EP}_{2}, \mathrm{EP}_{3}$, and $\mathrm{EP}_{4}$ subtypes of the PGE receptor, the PGF receptor (FP), the PGI receptor (IP), and the thromboxane $\mathrm{A}_{2}$ receptor (TP) (Samuelsson et al., 1978; Moncada et al., 1985; Halushka et al., 1989; Coleman et al., 1990; Negishi et al., 1995). These receptors can recognize the structural differences of prostanoid molecules. The binding affinities of these receptors to prostanoid molecules are determined primarily by the cyclopentane ring structures of ligands. For example, the DP receptor shows the highest affinities to $\mathrm{PGD}_{2}$ and $\mathrm{PGD}_{1}$, but affinities to other prostanoids are at least 2 orders of magnitude less. One exception is the IP receptor, which shows an affinity to $\mathrm{PGE}_{1}$ almost comparable to PGI analogs such as iloprost. This receptor, however, can bind $\mathrm{PGE}_{2}$ with much lower affinity, suggesting that the IP receptor can discriminate a difference in the side chains. The term "Kd" represents the affinity of a ligand for a particular receptor and it's inversely related to 
receptor affinity. The activation of membrane receptors and target cell responses is proportional to the degree of receptor occupancy.

The affinities of the prostanoid ligands for their specific receptors are as follows: $\mathrm{EP}_{1}$ receptor subtype had a $\mathrm{Kd}$ value of $21 \mathrm{nM}, \mathrm{EP}_{2}$ receptor subtype had a Kd value of $11 \mathrm{nM}, \mathrm{EP}_{3}$ receptor subtype had a $\mathrm{Kd}$ value of $3 \mathrm{nM}$, and the $\mathrm{EP}_{4}$ receptor subtype had a Kd value of $8.2 \mathrm{nM}$ for radioligand $\left[{ }^{3} \mathrm{H}\right] \mathrm{PGE}_{2}$ (Coleman et al., 1994; Bastepe et al., 1997). Thus, a PGE 2 response would be first seen with $\mathrm{PGE}_{2}$ binding the $\mathrm{EP}_{3}$ receptor subtype because it has $\mathrm{Kd}$ value of $3 \mathrm{nM}$ for radioligand $\left[{ }^{3} \mathrm{H}\right] P \mathrm{PE}_{2}$. While other EP receptors would require greater amounts of $\mathrm{PGE}_{2}$ to be come activated. The FP receptor type had Kd value of $1.3 \mathrm{nM}$ for radioligand $\left[{ }^{3} \mathrm{H}_{\mathrm{PGF}} \mathrm{PG}_{2 \alpha}\right.$; IP receptor type had $\mathrm{Kd}$ value described as $<10 \mathrm{nM}$ for radioligand $\left[{ }^{3} \mathrm{H}\right] 6-$ keto $\mathrm{PGF}_{1 \alpha}$, and mouse DP receptor type had Kd value of $43 \mathrm{nM}$ for radioligand $\left[{ }^{3} \mathrm{H}\right] \mathrm{PGD}_{2}$ (Coleman et al., 1994). Of the 8 receptors, $\mathrm{EP}_{4}, \mathrm{EP}_{1}, \mathrm{EP}_{2}, \mathrm{EP}_{3}$, $\mathrm{PGF}_{2 \alpha}$ (FPR), and $\mathrm{PGI}_{2}$ receptors have been found in bone and in osteoblastic cell lines (Miyaura et al., 2000; Suzawa et al., 2000; Nemoto et al., 1995; Wang et al., 1999).

The actions of prostaglandins produced by hOB cells will depend on the Kd value for the prostanoid and its specific receptor. For example, the Kd value of the $\mathrm{EP}_{3}$ receptor for $\mathrm{PGE}_{2}$ is $3 \mathrm{nM}$, and $\mathrm{PGE}_{2}$ production in hOB cells is approximately $27 \mathrm{nM}$. The FP receptor type has $\mathrm{Kd}$ value of $1.3 \mathrm{nM}$ for radioligand $\mathrm{PGF}_{2 \alpha}$, indicating that hOB cell production of $\mathrm{PGF}_{2 \alpha}(\sim 0.56 \mathrm{nM})$ should be sufficient to activate the FP receptor population in bone. However, hOB cell culture model doesnot exactly duplicate in vivo bone physiology, and the concentration of the PG 
products in the microenvironment of the cells wouldn't reflect the dilution by the cell culture media, and should be rather higher.

15-HETE was also measured in hOB cell cultures by EIA. Its basal level, 0.5 $\mathrm{ng} / \mathrm{ml}$, was in the general range of 6-keto-PGF ${ }_{1 \alpha}$ and $\mathrm{PGF}_{2 \alpha}$ basal levels. TGF $\beta$ and TNF $\alpha$ in combination elevated 15-HETE production in comparision to the levels measured in specimens treated with either TGF $\beta$ or TNF $\alpha$. 15-HETE production was inhibited by the COX inhibitor ibuprofen. These results are in agreement with thin layer chromatography (TLC) studies performed earlier in this laboratory, which demonstrated a band that co-migrated with authentic 15-HETE in hOB cell conditioned media, and that 15-HETE biosynthesis was eliminated in the presence of the NSAIDs aspirin or ibuprofen (P.Keeting, personal communication). A band tentatively identified as 12-HETE was also noted in the TLC studies, which appeared unaffected by cytokine addition. These findings are not inconsistent with work that showed that the amounts of all metabolites of lipoxygenases and cyclooxygenases were decreased by aspirin or indomethacin pretreatment in the perfused hamster lung tissue (Uotila et al., 1981; Schalin et al., 1982). However, typically the 15-LOX is not viewed as an NSAID target.

The steady-state level of hOB cell 15-lipoxygenase-II mRNA was responsive to modulation by TNF $\alpha$, and by TGF $\beta$ plus TNF $\alpha$ in combination. TGF $\beta$ alone had no demonstrable effect on 15-LOX-II mRNA levels in the hOB cells. Opposing interaction effects for TGF $\beta$ and TNF $\alpha$ mediation of 15-lipooxygenase-II mRNA expression in hOB cells was suggested, and when added concurrently TGF $\beta$ limited the TNF $\alpha$-mediated increase in 15-LOX-II mRNA levels. 
5-HETEs play an important role in bone research as suggested by studies on the involvement of 5-HETEs in bone resorption by activating osteoclasts (Gallwitz et al. 1993) and it might act as negative regulator of bone formation (Traianedes et al., 1998). While our studies do not address the role of the 15-HETEs in hOB cells and in bone remodeling, the identification 15-HETE production in hOB cells may serve to stimulate investigations aimed at such topics. Thus, the roles of the 15-HETEs and 15-LOX activity in bone remodeling and cellular signaling in osteoblasts is not clear since their presence was not previously documented; however, since they are produced in these cells, they may serve some mediator roles in bone remodeling, and thus, in the etiology and progression of bone disorders such as osteoporosis. However, it has been documented that 15-HETE has no proinflammatory capacity, but that it can inhibit the formation and the chemotactic response of neutrophils to leukotriene B4 (LTB4), a potent mediator of inflammation (Fogh et al., 1989). 15HETE inhibits carageenan-induced arthritis by lowering leukotriene B4 concentrations in the synovial fluid of dogs, indicating that it possesses antiinflammatory properties (Fogh et al., 1989).

Localized bone loss in rheumatoid arthritis results from the activation of an inflammatory immune response, which increases both the number and the activity of osteoclasts (Rehman et al., 2001). Elevated TNF- $\alpha$ levels can promote osteoclastogenesis by stimulating the osteoblasts/stromal cells and possibly $\mathrm{T}$ lymphocytes production of RANKL and M-CSF. In addition, recent in vitro studies have shown that TNF- $\alpha$, in the presence of M-CSF, directly induces the formation of multinucleated cells containing tartrate-resistant acid phosphatase that are fully 
capable of resorbing bone (Azuma et al., 2000; Kobayashi et al., 2000). Several antiinflammatory cytokines such as IL-10, IL-11, and IL-13 act by suppressing the production of inflammatory cytokines or by neutralizing them (Rehman et al., 2001). 15-HETE, because of its anti-inflammatory properties, may act by suppressing the production of inflammatory cytokines or by neutralizing them and may play a significant role in preventing bone loss. 


\section{REFERENCES}

Aarden EM, Burger EH, Nijweide PJ. (1994): Function of osteocytes in bone. J Cell Biochem 55:287.

Abe E, Yamamoto M, Taguchi Y, Lecka-Czernik B, Economides AN, Stahl N, Jilka RL, Manolagas SC. (2000): Essential requirement of BMPs 2/4 for both osteoblast and osteoclast formation in bone marrow cultures from adult mice: antagonism by noggin. J Bone Miner Res 15:663.

Abildgaard N, Brixen K, Eriksen EF, Kristensen JE, Nielsen JL, Heickendorff L. (2004): Sequential analysis of biochemical markers of bone resorption and bone densitometry in multiple myeloma. Haematologica 89:567.

Abramson S, Korchak H, Ludewig R, Edelson H, Haines K, Levin RI, Herman R, Rider L, Kimmel S, Weissmann G. (1985): Modes of action of aspirin-like drugs. Proc Natl Acad Sci U S A 82:7227.

Advani S, LaFrancis D, Bogdanovic E, Taxel P, Raisz LG, Kream BE. (1997): Dexamethasone suppresses in vivo levels of bone collagen synthesis in neonatal mice. Bone 20:41.

Akatsu T, Takahashi N, Udagawa N, Imamura K, Yamaguchi A, Sato K, Nagata N and Suda T. (1991): Role of prostaglandins in interleukin-1-induced bone resorption in mice in vitro. $\mathrm{J}$ Bone Miner Res 6:183.

Akune T, Ohba S, Kamekura S, Yamaguchi M, Chung UI, Kubota N, Terauchi Y, Harada Y, Azuma Y, Nakamura K, Kadowaki T, Kawaguchi H. (2004): PPARgamma insufficiency enhances osteogenesis through osteoblast formation from bone marrow progenitors. J Clin Invest 113:846.

Allen SH. (1993): Primary osteoporosis. Methods to combat bone loss that accompanies aging. Postgrad Med 93:43.

Anderson HC. (1995): Molecular biology of matrix vesicles. Clin Orthop 314:266.

Atkins D, Martin TJ. (1977): Rat osteogenic sarcoma cells: effects of some prostaglandins, their metabolites and analogues on cyclic AMP production. Prostaglandins 13:861. 
Aubin JE, Bonnelye E. (2000): Osteoprotegerin and its ligand: a new paradigm for regulation of osteoclastogenesis and bone resorption. Osteoporos Int 11:905.

Azuma Y, Kaji K, Katogi R, Takeshita S, Kudo A. (2000): Tumor necrosis factoralpha induces differentiation of and bone resorption by osteoclasts. J Biol Chem 275:4858.

Bilezikian JP, Morishima A, Bell J, Grumbach MM. (1998): Increased bone mass as a result of estrogen therapy in a man with aromatase deficiency. $\mathrm{N}$ Engl $\mathrm{J}$ Med 339:599.

Bonewald LF, Dallas SL. (1994): Role of active and latent transforming growth factor beta in bone formation. J Cell Biochem 294:55.

Borke JL, Eriksen EF, Minami J, Keeting P, Mann KG, Penniston JT, Riggs BL, Kumar R. (1988): Epitopes of the human erythrocyte Ca2+-Mg2+ ATPase pump in human osteoblast-like cell plasma membranes. J Clin Endocrinol Metab 67:1299.

Boskey AL. (1998): Biomineralization: conflicts, challenges, and opportunities. J Cell Biochem Suppl 30-31:83.

Boskey AL. (1996): Matrix proteins and mineralization: an overview. Connect Tissue Res 35:357.

Bossard MJ, Tomaszek TA, Thompson SK, Amegadzie BY, Hanning CR, Jones C, Kurdyla JT, McNulty DE, Drake FH, Gowen M, Levy MA. (1996):

Proteolytic activity of human osteoclast cathepsin K-expression, purification, activation, and substrate identification. J Biol Chem 271:12517.

Brash A, Boeglin W, Chang M. (1997): Discovery of a second 15-S-lipoxygenase in humans. Proc Natl Acad Sci U S A 94:6148.

Brash AR. (1999): Lipoxygenases: occurrence, functions, catalysis, and acquisition of substrate. J Biol Chem 274:23679.

Buckwalter, J. A., Glimcher, M. J., Cooper, R. R., and Recker, R. (1996): Bone biology. I. Structure, blood supply, cells, matrix, and mineralization. Inst Course Lect 45:371.

Castro-Malaspina H, Ebell W, Wang S. (1984): Human bone marrow fibroblast colony-forming units (CFU-F). Prog Clin Biol Res 154:209. 
Chambers TJ, Ali NN. (1983): Inhibition of osteoclastic motility by prostaglandins I2, E1, E2 and 6-oxo-E1. J Pathol 139:383.

Cissel DS, Murty M, Whipkey DL, Blaha JD, Graeber GM, Keeting PE. (1996): Estrogen pretreatment increases arachidonic acid release by bradykinin stimulated normal human osteoblast-like cells. J Cell Biochem 60:260.

Claveau D, Sirinyan M, Guay J, Gordon R, Chan CC, Bureau Y, Riendeau D, Mancini JA. (2003): Microsomal prostaglandin E synthase-1 is a major terminal synthase that is selectively up-regulated during cyclooxygenase-2dependent prostaglandin $\mathrm{E}_{2}$ production in the rat adjuvant-induced arthritis model. J. Immunol 70:4738.

Crofford LJ. (1997): COX-1 and COX-2 tissue expression: implications and predictions. J Rheumatol 24 Suppl 49:15.

Delany A, Amling M, Priemel M, Delling G, Howe C, Baron R, Canalis E. (1998): Osteonectin-null mice develop severe osteopenia. Bone 23:S199.

Delany AM, Amling M, Priemel M, Howe C, Baron R, Canalis E. (2000): Osteopenia and decreased bone formation in osteonectin-deficient mice. $\mathrm{J}$ Clin Invest 105:915.

Dempster DW, Cosman F, Parisien M, Shen V, Lindsay R. (1993): Anabolic actions of parathyroid hormone on bone. Endocr Rev 14:690.

Dewhirst FE. (1984): 6-Keto-prostaglandin E1-stimulated bone resorption in organ culture. Calcif Tissue Int 36:380.

Dodds RA, Merry K, Littlewood A, Gowen M. (1994): Expression of mRNA for IL1 beta, IL6 and TGF beta 1 in developing human bone and cartilage. J Histochem Cytochem 42:733.

Doggrell SA. (2003): Present and future pharmacotherapy for osteoporosis. Drugs Today (Barc) 39:633.

Ducy P, Desbois C, Boyce B, Pinero G, Story B, Dunstan C, Smith E, Bonadio J, Goldstein S, Gundberg C, Bradley A, Karsenty G. (1996): Increased bone formation in osteocalcin-deficient mice. Nature 382:448. 
Eriksen EF. (1986): Normal and pathological remodeling of human trabecular bone: three dimensional reconstruction of the remodeling sequence in normals and in metabolic bone disease. Endocr Rev 7:379.

Eriksen EF, Axelrod DW, Melsen F. (1994): Bone Histomorphometry. Raven Press, New York, pp 3.

Erlebacher A, Filvaroff EH, Gitelman SE, Derynck R (1995): Toward a molecular understanding of skeletal development. Cell 80:371.

Evans DB, Thavarajah M, Kanis JA. (1990): Involvement of prostaglandin E2 in the inhibition of osteocalcin synthesis by human osteoblast-like cells in response to cytokines and systemic hormones. Biochem Biophys Res Commun 167:194.

Farndale RW, Sandy JR, Atkinson SJ, Pennington SR, Meghji S, Meikle MC. (1988): Parathyroid hormone and prostaglandin E2 stimulate both inositol phosphates and cyclic AMP accumulation in mouse osteoblast cultures. Biochem J 252:263.

Flanagan AM, Chambers TJ. (1992): Stimulation of bone nodule formation in vitro by prostaglandins $\mathrm{E}_{1}$ and $\mathrm{E}_{2}$. Endocrinol 130:443.

Fogh K, Hansen ES, Herlin T, Knudsen V, Henriksen TB, Ewald H, Bunger C, Kragballe K. (1989): 15-Hydroxy-eicosatetraenoic acid, (15-HETE) inhibits carragheenan-induced experimental arthritis and reduces synovial fluid leukotriene B4 (LTB4). Prostaglandins 37:213.

Fontanges E, Fontana A, Delmas P. (2004): Osteoporosis and breast cancer. Joint Bone Spine 71:102.

Ford-Hutchinson A W. (1990): Arachidonic acid metabolism: enzymatic pathways. In: Eicosanoids and the Skin, Ed: Ruzick T, CRC Press, Boca Raton, 3.

Frost HM. (1963): Bone Remodeling Dynamics, Charles C. Thomas, Springfield, IL. Frost H M. (1973): Bone Remodeling and Its Relationship to Metabolic Bone Disease. Charles C. Thomas, Springfield, MA.

Fournier T, Fadok V, Henson PM. (1997): Tumor necrosis factor-alpha inversely regulates prostaglandin $\mathrm{D}_{2}$ and prostaglandin $\mathrm{E}_{2}$ production in murine 
macrophages. Synergistic action of cyclic AMP on cyclooxygenase-2 expression and prostaglandin $\mathrm{E}_{2}$ synthesis. J Biol Chem 272:31065.

Fujikawa Y, Sabokbar A, Neale SD, Itonaga I, Torisu T, Athanasou NA. (2001): The effect of macrophage-colony stimulating factor and other humoral factors (interleukin-1, -3, -6, and -11, tumor necrosis factor-alpha, and granulocyte macrophage-colony stimulating factor) on human osteoclast formation from circulating cells. Bone 28:261.

Fujishima H, Sanchez Mejia RO, Bingham CO 3rd, Lam BK, Sapirstein A, Bonventre JV, Austen KF, Arm JP. (1999): Cytosolic phospholipase A2 is essential for both the immediate and the delayed phases of eicosanoid generation in mouse bone marrow-derived mast cells. Proc Natl Acad Sci 96:4803.

Funk CD, Furci L, FitzGerald GA, Grygorczyk R, Rochette C, Bayne MA, Abramovitz M, Adam M, Metters KM. (1993): Cloning and expression of a cDNA for the human prostaglandin E receptor EP1 subtype. J Biol Chem 268:26767.

Funk CD. (2001): Prostaglandins and leukotrienes: Advances in eicosanoid biology. Science 294:1871.

Gallwitz WE, Mundy GR, Lee CH, Qiao M, Roodman GD, Raftery M, Gaskell SJ, Bonewald LF. (1993): 5-Lipoxygenase metabolites of arachidonic acid stimulate isolated osteoclasts to resorb calcified matrices. J Biol Chem 268:10087.

Gerdhem P, Ivaska KK, Alatalo SL, Halleen JM, Hellman J, Isaksson A, Pettersson K, Vaananen HK, Akesson K, Obrant KJ. (2004): Biochemical markers of bone metabolism and prediction of fracture in elderly women. J Bone Miner Res 19:386.

Ghilzon R, McCulloch CA, Zohar R. (1999): Stromal mesenchymal progenitor cells. Leuk Lymphoma 32:211.

Goppelt-Struebe M. (1995): Review: Regulation of prostaglandin endoperoxide synthase (cyclooxygenase) isozyme expression. Prost Leuko Essen Fatty Acids 52:213. 
Gori F, Hofbauer LC, Dunstan CR, Spelsberg TC, Khosla S, Riggs BL. (2000): The expression of osteoprotegerin and RANK ligand and the support of osteoclast formation by stromal-osteoblast lineage cells is developmentally regulated. Endocrinol 141:4768.

Gronowicz GA, Fall PM, Raisz LG. (1994): Prostaglandin E2 stimulates preosteoblast replication: an autoradiographic study in cultured fetal rat calvariae. Exp Cell Res 212:314.

Grzesik WJ, Robey PG. (1994): Bone matrix RGD glycoproteins: immunolocalization and interaction with human primary osteoblastic bone cells in vitro. J Bone Miner Res 9:487.

Hakeda Y, Yoshino T, Natakani Y, Kurihara N, Maeda N and Kumegawa M. (1986): Prostaglandin $\mathrm{E}_{2}$ stimulates DNA synthesis by a cyclic AMP-independent pathway in osteoblastic clone MC3T3-E1 cells. J Cell Physiol 128:155.

Hakeda Y, Hotta T, Kurihara N, Ikeda E, Maeda N, Yagyu Y, Kumegawa M. (1987): Prostaglandin E1 and F2 alpha stimulate differentiation and proliferation, respectively, of clonal osteoblastic MC3T3-E1 cells by different second messengers in vitro. Endocrinol 121:1966.

Hakeda Y, Kawaguchi H, Hurley M, Pilbeam CC, Abreu C, Linkhart TA, Mohan S, Kumegawa M, Raisz LG. (1996): Intact insulin-like growth factor binding protein-5 (IGFBP-5) associates with bone matrix and the soluble fragments of IGFBP-5 accumulated in culture medium of neonatal mouse calvariae by parathyroid hormone and prostaglandin $\mathrm{E}_{2}$-treatment. J Cell Physiol 166:370.

Han R, Tsui S, Smith TJ. (2002): Up-regulation of prostaglandin $E_{2}$ synthesis by interleukin-1beta in human orbital fibroblasts involves coordinate induction of prostaglandin-endoperoxide $\mathrm{H}$ synthase-2 and glutathione-dependent prostaglandin $E_{2}$ synthase expression. J Biol Chem 277:16355.

Hanson DA, Weis MA, Bollen AM, Maslan SL, Singer FR, Eyre DR. (1992): A specific immunoassay for monitoring human bone resorption: quantitation of type I collagen cross-linked N-telopeptides in urine. J Bone Miner Res $7: 1251$. 
Harris SG, Padilla J, Koumas L, Ray D, Phipps RP. (2002): Prostaglandins as modulators of immunity. Trends Immunol 23:144.

Hayman AR, Jones SJ, Boyde A, Foster D, Colledge WH, Carlton MB, Evans MJ, Cox TM. (1996): Mice lacking tartrate-resistant acid phosphatase (Acp 5) have disrupted endochondral ossification and mild osteopetrosis. Development 122:3151.

Hessle L, Johnson KA, Anderson HC, Narisawa S, Sali A, Goding JW, Terkeltaub R, Millan JL. (2002): Tissue-nonspecific alkaline phosphatase and plasma cell membrane glycoprotein-1 are central antagonistic regulators of bone mineralization. Proc Natl Acad Sci 99:9445.

Higgs GA, Salmon JA, Henderson B, Vane JR. (1987): Pharmacokinetics of aspirin and salicylate in relation to inhibition of arachidonate cyclooxygenase and antiinflammatory activity. Proc Natl Acad Sci U S A 84:1417.

Hightower L. (2000): Osteoporosis: pediatric disease with geriatric consequences. Orthop Nurs 19:59.

Hirschi KK, Goodell MA. (2002): Hematopoietic, vascular and cardiac fates of bone marrow-derived stem cells. Gene Ther 9:648.

Hodsman AB, Fraher LJ, Watson PH, Ostbye T, Stitt LW, Adachi JD, Taves DH, Drost D. (1997): A randomized controlled trial to compare the efficacy of cyclical parathyroid hormone versus cyclical parathyroid hormone and sequential calcitonin to improve bone mass in postmenopausal women with osteoporosis. J Clin Endocrinol Metab 82:620.

Hofbauer LC, Khosla S, Dunstan CR, Lacey DL, Boyle WJ, Riggs BL. (2000): The roles of osteoprotegerin and osteoprotegerin ligand in the paracrine regulation of bone resorption. J Bone Miner Res 15:2.

Horwood NJ, Elliott J, Martin TJ, Gillespie MT. (2001): IL-12 alone and in synergy with IL-18 inhibits osteoclast formation in vitro. J Immunol 166:4915.

Imamura Y, Steiglitz BM, Greenspan DS. (1998): Bone morphogenetic protein-1 processes the NH2-terminal propeptide, and a furin-like proprotein convertase processes the $\mathrm{COOH}$-terminal propeptide of pro-alpha1(V) collagen. J Biol Chem 273:27511. 
Inui K, Maeda H, Sano A, Fujioka K, Yutani Y, Sakawa A. (1998): Local application of basic fibroblast growth factor minipellet induces the healing of segmental bony defects in rabbits. Calcif Tissue Int 63:490.

Inzerillo AM, Zaidi M. (2002): Osteoporosis: trends and intervention. Mt Sinai J Med 69:220.

Islam A, Glomski C, Henderson ES. (1990): Bone lining (endosteal) cells and hematopoiesis: a light microscopic study of normal and pathologic human bone marrow in plastic-embedded sections. Anat Rec 227:300.

Jagels MA, Hugli TE. (2000): Mixed effects of TGF-beta on human airway epithelial-cell chemokine responses. Immunopharmacol 48:17.

Jakobsson, PJ, Thoren S, Morgenstern R, and Samuelsson B. (1999): Identification of human prostaglandin E synthase: a microsomal, glutathione-dependent, inducible enzyme, constituting a potential novel drug target. Proc. Natl. Acad. Sci. USA 96:7220.

Jee WS, Ueno K, Deng YP and Woodbury DM. (1985): The effects of prostaglandin E2 in growing rats: increased metaphyseal hard tissue and cortico-endosteal bone formation. Calcif Tissue Int 37: 148.

Jee WS, Ueno K, Kimmel DB, Woodbury DM, Price P and Woodbury LA. (1987): The role of bone cells in increasing metaphyseal hard tissue in rapidly growing rats treated with prostaglandin E2. Bone 8:171.

Jee WS, Mori S, Li XJ, Chan S. (1990): Prostaglandin $E_{2}$ enhances cortical bone mass and activates intracortical bone remodeling in intact and ovariectomized female rats. Bone 11:253.

Jilka RL, Manolagas SC (1994): The cellular and biochemical basis of bone remodeling. In Osteoporosis (ed. Marcus, R) p 17-37 Blackwell Scientific Publications, Boston.

Kamei D, Murakami M, Nakatani Y, Ishikawa Y, Ishii T, and Kudo I. (2003): Potential role of microsomal prostaglandin E synthase-1 in tumorigenesis. J Biol Chem 278:19396 
Kanaoka Y, Ago H, Inagaki E, Nanayama T, Miyano M, Kikuno R, Fujii Y, Eguchi N, Toh H, Urade Y, Hayaishi O. (1997): Cloning and crystal structure of hematopoietic prostaglandin D synthase. Cell 90:1085.

Katz JM, Wilson T, Skinner SJ, Gray DH. (1981): Bone resorption and prostaglandin production by mouse calvaria in vitro: response to exogenous prostaglandins and their precursor fatty acids. Prostaglandins 22:537.

Kawaguchi H, Pilbeam CC, Raisz LG. (1994): Anabolic effects of 3,3',5triiodothyronine and triiodothyroacetic acid in cultured neonatal mouse parietal bones. Endocrinol 135:971.

Kawaguchi H, Pilbeam CC, Harrison JR, Raisz LG. (1995): The role of prostaglandins in the regulation of bone metabolism. Clin Orthop 313:36.

Kawaguchi H, Nemoto K, Raisz LG, Harrison JR, Voznesensky OS, Alander CB, Pilbeam CC. (1996): Interleukin-4 inhibits prostaglandin G/H synthase-2 and cytosolic phospholipase A2 induction in neonatal mouse parietal bone cultures. J Bone Miner Res 11:358.

Khosla S. (2001): Minireview: the OPG/RANKL/RANK system. Endocrinol 142:5050.

Klein DC, Raisz LG. (1970): Prostaglandins: Stimulation of bone resorption in tissue culture. Endocrinol 86:1436.

Klein-Nulend J, Bowers PN, Raisz LG. (1990): Evidence that adenosine 3',5'monophosphate mediates hormonal stimulation of prostaglandin production in cultured mouse parietal bones. Endocrinol 126:1070.

Kliewer SA, Lenhard JM, Willson TM, Patel I, Morris DC, Lehmann JM. (1995): A prostaglandin J2 metabolite binds peroxisome proliferator-activated receptor gamma and promotes adipocyte differentiation. Cell 83:813.

Kobayashi K, Takahashi N, Jimi E, Udagawa N, Takami M, Kotake S, Nakagawa N, Kinosaki M, Yamaguchi K, Shima N, Yasuda H, Morinaga T, Higashio K, Martin TJ, Suda T. (2000): Tumor necrosis factor alpha stimulates osteoclast differentiation by a mechanism independent of the ODF/RANKL-RANK interaction. J Exp Med 191:275. 
Kostenuik PJ, Shalhoub V. (2001): Osteoprotegerin: a physiological and pharmacological inhibitor of bone resorption. Curr Pharm Des. 7:613.

Kulmacz RJ, Lands WE. (1985): Stoichiometry and kinetics of the interaction of prostaglandin $\mathrm{H}$ synthase with anti-inflammatory agents. J Biol Chem 260:12572.

Kuroki T, Shingu M, Koshihara Y, Nobunaga M. (1994): Effects of cytokines on alkaline phosphatase and osteocalcin production, calcification and calcium release by human osteoblastic cells. Br J Rheumatol 33:224.

Li YP, Stashenko P. (1992): Proinflammatory cytokines tumor necrosis factor-alpha and IL-6, but not IL-1, down-regulate the osteocalcin gene promoter. J Immunol 148:788.

Li YC, Amling M, Pirro AE, Priemel M, Meuse J, Baron R, Delling G, Demay MB. (1998): Normalization of mineral ion homeostasis by dietary means prevents hyperparathyroidism, rickets, and osteomalacia, but not alopecia in vitamin D receptor-ablated mice. Endocrinol 139:4391.

Limor R, Weisinger G, Gilad S, Knoll E, Sharon O, Jaffe A, Kohen F, Berger E, Mercer-Lifschizt B, Stern N. (2001): A novel form of platelet-type 12Lipoxygenase mRNA in human vascular smooth muscle cells. Hypertension 38:864.

Lorenzo JA. (1992): The role of cytokines in the regulation of local bone resorption. Crit Rev Immunol 11:195.

Manolagas SC, Bellido T, Jilka RL. (1995): Sex steroids, cytokines and the bone marrow: new concepts on the pathogenesis of osteoporosis. Ciba Found Symp 191:187-96; discussion 197.

Manolagas SC, Jilka RL. (1995): Bone marrow, cytokines, and bone remodeling. Emerging insights into the pathophysiology of osteoporosis. N Engl J Med 332:305.

Manolagas SC. (1998): Cellular and molecular mechanisms of osteoporosis. Aging (Milano) 10:182. 
Manolagas SC. (2000): Birth and death of bone cells: basic regulatory mechanisms and implications for pathogenesis and treatment of osteoporosis. Endocrine Rev 21:115.

Marie PJ. (1994): Human osteoblastic cells: a potential tool to assess the etiology of pathologic bone formation. J Bone Miner Res 9:1847.

Marks SC, Popoff SN. (1988): Bone cell biology: The regulation of development, structure, and function in the skeleton. Am J Anat 183:1.

Marotti G, Cane V, Palazzini S, Palumbo C. (1990): Structure-function relationships in the osteocyte. Ital J Miner Electro Metab 4:93.

Marotti G (1996): The structure of bone tissues and the cellular control of their deposition. Ital J Anat Embryol 101:25.

Masi L, Brandi ML. (2001): Physiopathological basis of bone turnover. Q J Nucl Med 45:2.

McCulloch CAG, Struguresco M, Hughes F, Melcher AH, Aubin JE. (1991):

Osteogenic precursor cells in rat bone marrow stromal populations exhibit self-renewal in culture. Blood 77:1906.

McLeod KJ, Rubin CT, Otter MW, Qin YX. (1998): Skeletal cell stresses and bone adaptation. Am J Med Sci 316:176.

Meghji S, Sandy JR, Scutt AM, Harvey W, Harris M. (1988): Stimulation of bone resorption by lipoxygenase metabolites of arachidonic acid. Prostaglandins 36:139.

Miller SC, Marks SC Jr. (1994): Effects of prostaglandins on the skeleton. Clin Plast Surg 21:393.

Mills BG, Frausto A. (1997): Cytokines expressed in multinucleated cells: Paget's disease and giant cell tumors versus normal bone. Calcif Tissue Int 61:16.

Miyaura C, Inada M, Suzawa T, Sugimoto Y, Ushikubi F, Ichikawa A, Narumiya S, Suda T. (2000): Impaired bone resorption to prostaglandin $E_{2}$ in

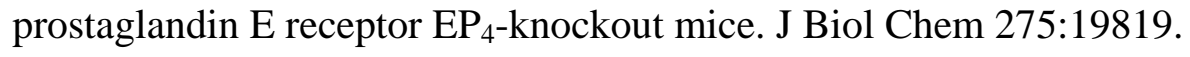

Mori S, Jee WS, Li XJ, Chan S, Kimmel DB. (1990): Effects of prostaglandin $E_{2}$ on production of new cancellous bone in the axial skeleton of ovariectomized rats. Bone 11: 103. 
Mori S, Jee WS, Li XJ. (1992): Production of new trabecular bone in osteopenic ovariectomized rats by prostaglandin $\mathrm{E}_{2}$. Calcif Tissue Int 50:80.

Mosley JR (2000): Osteoporosis and bone functional adaptation: mechanobiological regulation of bone architecture in growing and adult bone, a review. $\mathrm{J}$ Rehabil Res Dev 37:189.

Mulari MT, Qu Q, Harkonen PL, Vaananen HK. (2004): Osteoblast-like Cells Complete Osteoclastic Bone Resorption and Form New Mineralized Bone Matrix In Vitro. Calcif Tissue Int [Epub ahead of print]

Mundy G R. (1994): Peptides and growth regulatory factors in bone. Rheum Dis Clin North Am 20:577.

Murakami M, Kambe T, Shimbara S, Kudo I. (1999): Functional coupling between various phospholipase A2s and cyclooxygenases in immediate and delayed prostanoid biosynthetic pathways. J Biol Chem 274:3103.

Murakami M, Naraba H, Tanioka T, Semmyo N, Nakatani Y, Kojima F, Ikeda T, Fueki M, Ueno A, Oh-Ishi S, Kudo I. (2000): Regulation of prostaglandin E2 biosynthesis by inducible membrane-associated prostaglandin $\mathrm{E}_{2}$ synthase that acts in concert with cyclooxygenase-2. J Biol Chem 275:32783.

Murakami M, Nakatani Y, Tanioka T, Kudo I. (2002): Prostaglandin E synthase. Prostaglandins Other Lipid Mediat 68-69:383.

Nakatani Y, Kudo I. (2002): Prostaglandin E2 synthases. Nippon Yakurigaku Zasshi $120: 373$

Naraba H, Yokoyama C, Tago N, Murakami M, Kudo I, Fueki M, Oh-Ishi S, Tanabe T. (2002): Transcriptional regulation of the membrane-associated prostaglandin $\mathrm{E}_{2}$ synthase gene. Essential role of the transcription factor Egr1. J Biol Chem 277: 28601.

Natarajan S, Nietert PJ. (2003): National trends in screening, prevalence, and treatment of cardiovascular risk factors. Prev Med 36:389.

Navamani M, Morgan M, Williams J. (1997): Ethanol modulates N-methyl-Daspartate-evoked arachidonic acid release from neurones. Eur J Pharmacol 340:27. 
Negishi M, Sugimoto Y, Ichikawa A. (1995): Molecular mechanisms of diverse actions of prostanoid receptors. Biochim Biophys Acta 1259:109.

Nemoto K, Bernecker PM, Pilbeam CC, Raisz LG. (1995): Expression and regulation of prostaglandin $\mathrm{F}$ receptor mRNA in rodent osteoblastic cells. Prostaglandins 50:349.

Nemoto K, Pilbeam CC, Bilak SR, Raisz LG. (1997): Molecular cloning and expression of a rat prostaglandin $\mathrm{E}_{2}$ receptor of the $\mathrm{EP}_{2}$ subtype.

Prostaglandins 54:713.

Neuman WF, MW Neuman. 1958. Skeletal dynamics. In The Chemical Dynamics of Bone Mineral. University of Chicago Press, Chicago, IL. 101.

Newton R, Kuitert LM, Slater DM, Adcock IM, Barnes PJ. (1997): Cytokine induction of cytosolic phospholipase A2 and cyclooxygenase-2 mRNA is suppressed by glucocorticoids in human epithelial cells. Life Sci 60:67.

Nijweide PJ, Burger EH, Klein-Nulend J, van der Pluijm G (1996): The Osteocyte. In: Bilezikian JP, Raisz LG, Rodan GA (eds) Principles of Bone Biology. Academic Press, San Diego, CA, pp 115.

Norman AW. (1992): Bone biochemistry and physiology from the perspectives of the vitamin D endocrine system. Curr Opin Rheumatol 4:375.

Nugteren DH, Kivits GA. (1987): Conversion of linoleic acid and arachidonic acid by skin epidermal lipoxygenases. Biochim Biophys Acta 921:135.

Nuttall ME, Gimble JM. (2004): Controlling the balance between osteoblastogenesis and adipogenesis and the consequent therapeutic implications. Curr Opin Pharmacol 4:290.

Okada Y, Pilbeam C, Raisz L, Tanaka Y. (2003): Role of cyclooxygenase-2 in bone resorption. J UOEH 25:185.

Ono K, Akatsu T, Murakami T, Nishikawa M, Yamamoto M, Kugai N, Motoyoshi K, Nagata N. (1998): Important role of $\mathrm{EP}_{4}$, a subtype of prostaglandin (PG) E receptor, in osteoclast-like cell formation from mouse bone marrow cells induced by PGE2. J Endocrinol 158:R1. 
Owen M (1985): Lineage of osteogenic cells and their relationship to the stromal system. In: Peck WA (ed) Bone and Mineral Research. Elsevier, Amsterdam 3:1.

Owens JM, Gallagher AC, Chambers TJ. (1996): IL-10 modulates formation of osteoclasts in murine hemopoietic cultures. J Immunol 157:936.

Pacifici R. (1996): Estrogen, cytokines and pathogenesis of postmenopausal osteoporosis. J Bone Miner Res 11:1043.

Pacifici R. (1998): Cytokines, estrogen and postmenopausal osteoporosis-the second decade. Endocrinol 139:2659.

Parfitt AM. (1984): The cellular basis of bone remodeling: the quantum concept reexamined in light of recent advances in the cell biology of bone. Calcif Tissue Int 36 Suppl 1:S37.

Parfitt AM. (1994): Osteonal and hemi-osteonal remodeling: the spatial and temporal framework for signal traffic in adult human bone. J Cell Biochem 55:273.

Parfitt AM (1996): Skeletal heterogeneity and the purposes of bone remodeling: Implications for the understanding of osteoporosis. In: Marcus R, Feldman D, Kelsey J (eds) Osteoporosis. Academic Press, San Diego, CA, pp 315.

Partridge NC, Kemp BE, Veroni MC, Martin TJ. (1981): Activation of adenosine 3',5'-monophosphate-dependent protein kinase in normal and malignant bone cells by parathyroid hormone, prostaglandin E2, and prostacyclin. Endocrinol 108:220.

Pawluczyk IZ, Harris KP. (1998): Cytokine interactions promote synergistic fibronectin accumulation by mesangial cells. Kidney Int 54:62.

Pfeilschifter J, Pignat W, Vosbeck K, Marki F. (1989): Interleukin 1 and tumor necrosis factor synergistically stimulate prostaglandin synthesis and phospholipase A2 release from rat renal mesangial cells. Biochem Biophys Res Commun 159:385.

Pei L, Tontonoz P. (2004): Fat's loss is bone's gain. J Clin Invest 113:805. Pilbeam C, Rao Y, Voznesensky O, Kawaguchi H, Alander C, Raisz L, Herschman H. (1997): Transforming growth factor-beta1 regulation of prostaglandin $\mathrm{G} / \mathrm{H}$ synthase-2 expression in osteoblastic MC3T3-E1 cells. Endocrinol 138:4672. 
Plotkin LI, Weinstein RS, Parfitt AM, Roberson PK, Manolagas SC, Bellido T. (1999): Prevention of osteocyte and osteoblast apoptosis by bisphosphonates and calcitonin. J Clin Invest 104:1363.

Pittenger MF, Mackay AM, Beck SC, Jaiswal RK, Douglas R, Mosca JD, Moorman MA, Simonetti DW, Craig S, Marshak DR (1999): Multilineage potential of adult human mesenchymal stem cells. Science 284:143.

Prestwood KM, Kenny AM. (1998): Osteoporosis: pathogenesis, diagnosis, and treatment in older adults. Clin Geriatr Med 14:577.

Prockop, DJ. (1997): Marrow Stromal Cells as Stem Cells for Nonhematopoietic Tissues. Science 276: 71.

Pruzanski W, Stefanski E, Vadas P, Kennedy BP, van den Bosch H. (1998):

Regulation of the cellular expression of secretory and cytosolic phospholipases A2, and cyclooxygenase-2 by peptide growth factors. Biochim Biophys Acta 1403:47.

Raisz LG, Trummel CL, Mundy GR, Luben RA. (1975): Immunologic factors influencing bone resorption, role of osteoclast activating factor from human lymphocytes and complement mediated prostaglandin synthesis. In CalciumRegulating Hormones, Talmage RV, Owen M, Parsons JA, editors. Excerpta Medica, Amsterdam. 149.

Raisz LG, Vanderhoek JY, Simmons HA, Kream BE, Nicolaou KC. (1979): Prostaglandin synthesis by fetal rat bone in vitro: evidence for a role of prostacyclin. Prostaglandins 17:905.

Raisz LG, Kream BE. (1983): Regulation of bone formation. New England Journal of Medicine 309:29.

Raisz LG, Martin TJ. (1983): Bone and Mineral Research, Annual 2 (ed. WA Peck) Elsevier Sci.

Raisz LG, Johannesson A. (1984): Pathogenesis, prevention and therapy of osteoporosis. J Med 15:267.

Raisz LG. (1988): Ciba Found Symp 136:226. 
Raisz LG, Alander CB, Fall PM, Simmons HA. (1990): Effects of prostaglandin $F_{2}$ alpha on bone formation and resorption in cultured neonatal mouse calvariae: Role of prostaglandin $E_{2}$ production. Endocrinol 126: 1076.

Raisz, LG. (1993): Bone cell biology: New approaches and unanswered questions. J Bone Min Res 8:S457.

Raisz LG, Pilbeam CC, Fall PM. (1993): Prostaglandins: mechanisms of action and regulation of production in bone. Osteoporos Int 3 Suppl 1:136.

Raisz LG, Fall PM, Petersen DN, Lichtler A, Kream BE. (1993): Prostaglandin E2 inhibits alpha 1(I)procollagen gene transcription and promoter activity in the immortalized rat osteoblastic clonal cell line Py1a. Mol Endocrinol 7:17.

Raisz LG. (1995): Physiologic and pathologic roles of prostaglandins and other eicosanoids in bone. J Nutr 125: 2024S.

Raisz LG. (1999): Physiology and pathophysiology of bone remodeling. Clin Chem 45:1353.

Ralston SH. (1997): Osteoporosis. Brit Med J 315:469.

Ramos EL, Barri YM, Croker BP, Clapp WL, Peterson JC, Wilcox CS. (1995): Thromboxane synthase expression in renal transplant patients with rejection. Transplantation 59:490.

Ray NF, Chan JK, Thamer M, Melton LJ. (1997): Medical expenditures for the treatment of osteoporotic fractures in the United States in 1995: report from the National Osteoporosis Foundation. J Bone Miner Res 12:24.

Reddi, AH (1997): Bone morphogenesis and modeling: soluble signals sculpt osteosomes in the solid state. Cell 89:159.

Rehman Q, Lane NE. (2001): Bone loss. Therapeutic approaches for preventing bone loss in inflammatory arthritis. Arthritis Res 3:221.

Rho J, Takami M, Choi Y. (2004): Osteoimmunology: interactions of the immune and skeletal systems. Mol Cells 17:1.

Rifas L, Halstead LR, Peck WA, Avioli LV, Welgus HG. (1989): Human osteoblasts in vitro secrete tissue inhibitor of metalloproteinases and gelatinase but not interstitial collagenase as major cellular products. J Clin Invest 84:686. 
Riggs BL, Melton LJ. (1992): The prevention and treatment of osteoporosis. New Engl J Med 327:620.

Robey PG, Termine JD. (1985): Human bone cells in vitro. Calcif Tissue Int 37:453.

Robinson RA, Elliot SR. (1957): The water content of bone. J Bone Jt Surg 39A:167.

Rodan GA, Noda M. (1991): Gene expression in osteoblastic cells. Crit Rev Eukaryot Gene Expr 1:85.

Roodman GD. (1996): Advances in bone biology: the osteoclast. Endocr Rev 17:308.

Rosen V, Cox K, Hattersley G. (1996): Bone morphogenetic proteins. In: Bilezikian JP, Raisz LG, Rodan GA (eds) Principles of Bone Biology. Academic Press, San Diego, CA, pp 661.

Rosen CJ, Donahue LR. (1998): Insulin-like growth factors and bone-the osteoporosis connection revisited. Proc Soc Exp Biol Med 219:1.

Saegusa M, Murakami M, Nakatani Y, Yamakawa K, Katagiri M, Matsuda K, Nakamura K, Kudo I, Kawaguchi H. (2003): Contribution of membraneassociated prostaglandin E2 synthase to bone resorption. J Cell Physiol 197:348.

Sakou T. (1998): Bone morphogenetic proteins: from basic studies to clinical approaches. Bone 22:591.

Sakuma Y, Tanaka K, Suda M, Yasoda A, Natsui K, Tanaka I, Ushikubi F, Narumiya S, Segi E, Sugimoto Y, Ichikawa A, Nakao K. (2000): Crucial involvement of the $\mathrm{EP}_{4}$ subtype of prostaglandin $\mathrm{E}$ receptor in osteoclast formation by proinflammatory cytokines and lipopolysaccharide. J Bone Miner Res 15:218.

Salo J, Lehenkari P, Mulari M, Metsikkö K, Väänänen HK. (1997): Removal of osteoclast bone resorption products by transcytosis. Science 276:270.

Samuelsson B. (1983): From studies of biochemical mechanism to novel biological mediators: prostaglandin endoperoxides, thromboxanes, and leukotrienes. Nobel Lecture, 8 December 1982. Biosci Rep 3:791.

Samuelsson B. (1987): An elucidation of the arachidonic acid cascade. Discovery of prostaglandins, thromboxane and leukotrienes. Drugs 33 Suppl 1:2. 
Schalin M, Uotila P. (1982): The effect of aspirin pretreatment on the fate of arachidonic acid in hamster isolated lungs. Prostaglandins Leukot Med 9:171.

Schor AM, Canfield AE, Sutton AB, Arciniegas E, Allen TD (1995): Pericyte differentiation. Clin Orthop 313:81.

Shen V, Rifas L, Kohler G, Peck WA. (1986): Prostaglandins change cell shape and increase intercellular gap junctions in osteoblasts cultured from rat fetal calvaria. J Bone Miner Res 1:243.

Secreto FJ, Grover A, Pacurari M, Rice MB, Kantorow M, Bidwai AP, Blaha JD, Keeting PE. (2003): Estrogen potentiates the combined effects of transforming growth factor-beta and tumor necrosis factor-alpha on adult human osteoblast-like cell prostaglandin E2 biosynthesis. Calcif Tissue Int 73:565-74.

Seeman E. (2003): Invited Review: Pathogenesis of osteoporosis. J Appl Physiol 95:2142.

Six DA, Dennis EA. (2000): The expanding superfamily of phospholipase A(2) enzymes: classification and characterization. Biochim Biophys Acta 1488:1.

Smith WL, Dewitt DL. (1996): Prostaglandin endoperoxide H synthases-1 and -2. Adv Immunol 62:167.

Smith WL, DeWitt DL, RM Garavito. (2000): Cyclooxygenases: Structural, Cellular and Molecular Biology. Annu. Rev. Biochem 69:146.

Smith, WL. (1992): Prostanoid biosynthesis and mechanisms of action. Am. J. Physiol 263: F181.

Soler M, Camacho M, Escudero JR, Iniguez MA, Vila L. (2000): Human vascular smooth muscle cells but not endothelial cells express prostaglandin E synthase. Circ Res 87:504.

Sporn MB, Todaro GJ. (1980): Autocrine secretion and malignant transformation of cells. N Engl J Med 303:878.

Stein GS, Lian JB. (1993): Molecular mechanisms mediating proliferation/differentiation interrelationships during progressive development of the osteoblast phenotype. Endocr Rev 14:424. 
Stepan JJ, Alenfeld F, Boivin G, Feyen JH, Lakatos P. (2003): Mechanisms of action of antiresorptive therapies of postmenopausal osteoporosis. Endocr Regul 37:225.

Stichtenoth DO, Thoren S, Bian H, Peters-Golden M, Jakobsson PJ, Crofford LJ. (2001): Microsomal prostaglandin E synthase is regulated by proinflammatory cytokines and glucocorticoids in primary rheumatoid synovial cells. J Immunol 167:469.

Suda M, Tanaka K, Natsui K, Usui T, Tanaka I, Fukushima M, Shigeno C, Konishi J, Narumiya S, Ichikawa A, Nakao K. (1996): Prostaglandin E receptor subtypes in mouse osteoblastic cell line. Endocrinol 137:1698.

Suda T, Takahashi N, Martin TJ (1992): Modulation of osteoclast differentiation. Endocr Rev 13:66.

Suda M, Tanaka K, Yasoda A, Natsui K, Sakuma Y, Tanaka I, Ushikubi F, Narumiya S, Nakao K. (1998): Prostaglandin $\mathrm{E}_{2}\left(\mathrm{PGE}_{2}\right)$ autoamplifies its production through EP1 subtype of PGE receptor in mouse osteoblastic MC3T3-E1 cells. Calcif Tissue Int 62:327.

Suda T, Takahashi N, Udagawa N, Jimi E, Gillespie MT, Martin TJ. (1999):

Modulation of osteoclast differentiation and function by the new members of the tumor necrosis factor receptor and ligand families. Endocr Rev 20:345.

Suda M, Tanaka K, Sakuma Y, Yasoda A, Ozasa A, Fukata J, Tanaka I, Narumiya S, Nakao K. (2000): Prostaglandin E(2) (PGE(2)) induces the c-fos and c-jun expressions via the $\mathrm{EP}\left({ }_{1}\right)$ subtype of PGE receptor in mouse osteoblastic MC3T3-E1 cells. Calcif Tissue Int 66:217.

Suzawa T, Miyaura C, Inada M, Maruyama T, Sugimoto Y, Ushikubi F, Ichikawa A, Narumiya S, Suda T. (2000): The role of prostaglandin E receptor subtypes (EP1, EP2, EP3, and EP4) in bone resorption: an analysis using specific agonists for the respective EPs. Endocrinol 141:1554.

Suzuki T, Fujii Y, Miyano M, Chen LY, Takahashi T, Watanabe K. (1999): cDNA Cloning, Expression, and Mutagenesis Study of Liver-type Prostaglandin F Synthase. J Biol Chem 274:241. 
Suzuki-Yamamoto T, Yokoi H, Tsuruo Y, Watanabe K, Ishimura K. (1999):

Identification of prostaglandin F-producing cells in the liver. Histochem Cell Biol 112:451.

Suzuki-Yamamoto T, Toida K, Tsuruo Y, Watanabe K, Ishimura K. (2000):

Immunocytochemical localization of lung-type prostaglandin F synthase in the rat spinal cord. Brain Res 877:391.

Takahashi N, Udagawa N, Akatsu T, Tanaka H, Shionome M, Suda T. (1991): Role of colony-stimulating factors in osteoclast development. J Bone Miner Res 6:977.

Takahashi Y, Reddy GR, Ueda N, Yamamoto S, Arase S. (1993): Arachidonate 12lipoxygenase of platelet-type in human epidermal cells. J Biol Chem 268:16443.

Takahashi N, Udagawa N, Suda T. (1999): A new member of tumor necrosis factor ligand family, ODF/OPGL/TRANCE/RANKL, regulates osteoclast differentiation and function. Biochem Biophys Res Commun 24;256:449.

Tang DG, Chen YQ, Honn KV. (1996): Arachidonate lipoxygenases as essential regulators of cell survival and apoptosis. Proc Natl Acad Sci USA 93, 5241. Tanioka T, Nakatani Y, Semmyo N, Murakami M, Kudo I. (2000): Molecular identification of cytosolic prostaglandin $\mathrm{E}_{2}$ synthase that is functionally coupled with cyclooxygenase-1 in immediate prostaglandin $\mathrm{E}_{2}$ biosynthesis. $\mathrm{J}$ Biol Chem 275:32775.

Tang S, Bhatia B, Maldonado CJ, Yang P, Newman RA, Liu J, Chandra D, Traag J, Klein RD, Fischer SM, Chopra D, Shen J, Zhau HE, Chung LW, Tang DG. (2002): Evidence that arachidonate 15-lipoxygenase 2 is a negative cell cycle regulator in normal prostate epithelial cells. J Biol Chem 277:16189.

Tasaki Y, Takamori R, Koshihara Y. (1991): Prostaglandin D2 metabolite stimulates collagen synthesis by human osteoblasts during calcification. Prostaglandins 41:303.

Tashjian AH Jr., Bosma TJ, Levine L. (1988): Use of minoxidil to demonstrate that prostacyclin is not the mediator of bone resorption stimulated by growth factors in mouse calvariae. Endocrinology 123:969. 
Termine JD, Kleinman HK, Whitson SW, Conn KM, McGarvey ML, Martin GR. (1981): Osteonectin, a bone-specific protein linking mineral to collagen. Cell 26:99.

Thoren S, Weinander R, Saha S, Jegerschold C, Pettersson PL, Samuelsson B, Hebert H, Hamberg M, Morgenstern R, and Jakobsson PJ. (2003): Human microsomal prostaglandin E synthase-1: purification, functional characterization, and projection structure determination. J Biol Chem 278:22199.

Tomkinson A, Gevers EF, Wit JM, Reeve J, Noble BS (1998): The role of estrogen in the control of rat osteocyte apoptosis. J Bone Miner Res 13:1243.

Udagawa N, Takahashi N, Akatsu T, Tanaka H, Sasaki T, Nishihara T, Koga T, Martin TJ, Suda T (1990): Origin of osteoclasts: mature monocytes and macrophages are capable of differentiating into osteoclasts under a suitable microenvironment prepared by bone marrow-derived stromal cells. Proc Natl Acad Sci USA 87:7260.

Uotila P, Mannisto J, Simberg N, Hartiala K. (1981): Indomethacin inhibits arachidonic acid metabolism via lipoxygenase and cyclo-oxygenase in hamster isolated lungs. Prostaglandins Med 7:591.

Urade Y, Eguchi N. (2002): Lipocalin-type and hematopoietic prostaglandin D synthases as a novel example of functional convergence. Prostaglandins Other Lipid Mediat 68-69:375.

Urade Y, Hayaishi O. (2000): Prostaglandin D synthase: structure and function. Vitam Horm 58:89.

Vaes G. (1988): Cellular biology and biochemical mechanism of bone resorption. A review of recent developments on the formation, activation, and mode of action of osteoclasts. Clin Orthop 231:239.

Vane JR. (1971): Inhibition of prostaglandin biosynthesis as a mechanism of action of aspirin-like drugs. Nat New Biol 231:232.

Vane JR. (1994): Towards a better aspirin. Nature 367:215.

Vane JR, YS Bakhle, Botting RM. (1998): Cyclooxygenases 1 and 2. Annu Rev Pharmacol Toxicol 38:97. 
Vrotsos Y, Miller SC, Marks SC Jr. (2003): Prostaglandin E--a powerful anabolic agent for generalized or site-specific bone formation. Crit Rev Eukaryot Gene Expr 13:255.

Walsh SW. (1989): Low-dose aspirin: treatment for the imbalance of increased thromboxane and decreased prostacyclin in preeclampsia. Am J Perinatol $6: 124$.

Walsh SW. (2004): Eicosanoids in preeclampsia. Prostaglandins Leukot Essent Fatty Acids 70:223.

Wang J, Yamamoto K, Sugimoto Y, Ichikawa A, Yamamoto S. (1999): Induction of prostaglandin I(2) receptor by tumor necrosis factor alpha in osteoblastic MC3T3-E1 cells. Biochim Biophys Acta 1441:69.

Watanabe H, Yanagisawa T, Sasaki J. (1995). Cytoskeletal architecture of rat calvarial osteoclasts: microfilaments, and intermediate filaments, and nuclear matrix as demonstrated by detergent perfusion. Anat Rec 243:165.

Weinreb M, Grosskopf A, Shir N. (1999): The anabolic effect of PGE2 in rat bone marrow cultures is mediated via the $\mathrm{EP}_{4}$ receptor subtype. Am J Physiol 276:E376.

Weinstein RS, Jilka RL, Parfitt AM, Manolagas SC. (1998): Inhibition of osteoblastogenesis and promotion of apoptosis of osteoblasts and osteocytes by glucocorticoids: potential mechanisms of their deleterious effects on bone. J Clin Invest 102:274.

Welch RD, Johnston CE 2nd, Waldron MJ, Poteet B. (1993): Intraosseous infusion of prostaglandin $\mathrm{E}_{2}$ in the caprine tibia. J Orthop Res 11:110.

Wen Y, Gu J, Knaus UG, Thomas L, Gonzales N, Nadler J. (2000): Evidence that 12-lipoxygenase product 12-hydroxyeicosatetranoic acid activates p21activated kinase. Biochem J 349:481.

Wennberg C, Hessle L, Lundberg P, Mauro S, Narisawa S, Lerner UH, Millan JL. (2000): Functional characterization of osteoblasts and osteoclasts from alkaline phosphatase knockout mice. J Bone Miner Res 15:1879.

Whitfield JF, Morley P, Willick GE. (2002): Bone growth stimulators. New tools for treating bone loss and mending fractures. Vitam Horm 65:1. 
Whyte MP. (1994): Hypophosphatasia and the role of alkaline phosphatase in skeletal mineralization. Endocr Rev 15:439.

Yamagata K, Matsumura K, Inoue W, Shiraki T, Suzuki K, Yasuda S, Sugiura H, Cao C, Watanabe Y, Kobayashi S. (2001): Coexpression of microsomal-type prostaglandin E synthase with cyclooxygenase-2 in brain endothelial cells of rats during endotoxin-induced fever. J Neurosci 21:2669.

Yanaga F, Abe M, Koga T, Hirata M. (1992): Signal transduction by tumor necrosis factor alpha is mediated through a guanine nucleotide-binding protein in osteoblast-like cell line, MC3T3-E1. J Biol Chem 267:5114.

Yasuda H, Shima N, Nakagawa N, Yamaguchi K, Kinosaki M, Goto M, Mochizuki SI, Tsuda E, Morinaga T, Udagawa N, Takahashi N, Suda T, Higashio K. (1999): A novel molecular mechanism modulating osteoclast differentiation and function. Bone 25:109.

Xu J, Cissel DS, Varghese S, Whipkey DL, Blaha JD, Graeber GM, Keeting PE. (1997): Cytokine regulation of adult human osteoblast-like cell prostaglandin biosynthesis. J Cell Biochem 64:618.

Yu JH, Wells H, Ryan WJ, Lloyd WS. (1976): Effects of prostaglandins and other drugs on the cyclic AMP content of cultured bone cells. Prostaglandins 12:501. 